\title{
12. LOWER OLIGOCENE ICE-RAFTED DEBRIS ON THE KERGUELEN PLATEAU: EVIDENCE FOR EAST ANTARCTIC CONTINENTAL GLACIATION ${ }^{1}$
}

\author{
James R. Breza ${ }^{2}$ and Sherwood W. Wise, Jr. ${ }^{2}$
}

\begin{abstract}
Appreciable lower Oligocene clastic detritus interpreted to be ice-rafted debris (IRD) was recovered at Ocean Drilling Program (ODP) Site 748 on the Central Kerguelen Plateau in the southern Indian Ocean. Site 748 is located in the western part of the Raggatt Basin, east of Banzare Bank at $58^{\circ} 26.45^{\prime} \mathrm{S}, 78^{\circ} 58.89^{\prime} \mathrm{E}$ (water depth $=1250 \mathrm{~m}$ ). The physiologic and tectonic setting of the site and the coarse size of the material rule out transport of the clastics by turbidity currents, nepheloid layers, or wind.

The IRD occurs between 115.45 and 115.77 mbsf within a stratum of siliceous nannofossil ooze in an Oligocene sequence otherwise composed exclusively of nannofossil ooze with foraminifers and siliceous debris. Glauconite and fish skeletal debris (ichthyolith fragments) occur in association with the IRD. According to planktonic foraminifer, diatom, and nannofossil biostratigraphy and magnetostratigraphy, the IRD interval is earliest Oligocene in age (35.8-36.0 Ma). The sedimentation rate throughout this interval was rather low (approximately $6.3 \mathrm{~m} / \mathrm{m} . \mathrm{y}$.). The IRD consists of predominately fine to coarse sand composed of quartz, altered feldspars, and mica. A large portion of the quartz and feldspar grains is highly angular, and fresh conchoidal fractures on the quartz grains are characteristic of glacially derived material. Scanning electron microscope and energy-dispersive X-ray studies plus light microscope observations document the presence of a heavy-mineral suite characteristic of metamorphic or plutonic source rocks rather than that derived from the devitrification of a volcanic ash. Benthic foraminifer $\delta^{18} \mathrm{O}$ values across this interval show a marked enrichment.

This direct physical evidence of lower Oligocene IRD this far north of the Antarctic continent (the lowest latitudinal occurrence known) and the association of the IRD with the globally recognized shift in $\delta^{18} \mathrm{O}$ argue strongly for the presence of an earliest Oligocene ice sheet on the Antarctic continent. This corroborates other recent drilling evidence of coeval glacial activity along the Antarctic margin (ODP Legs 113 and 119) and in the Ross Sea (CIROS-1), as well as previous indirect evidence based on stable isotope studies from the world's oceans.

The co-occurrence of the IRD, biosiliceous-rich nannofossil ooze, fish skeletal debris, and glauconite probably denotes changes in patterns and/or intensity of oceanic circulation associated with a profound climatic cooling. These changes apparently enhanced upwelling and surface-water productivity and the development of a trophic structure that supported abundant vertebrate marine life, perhaps an important step in the evolution of vertebrate marine faunas.
\end{abstract}

\section{INTRODUCTION}

One of the major discoveries of Ocean Drilling Program (ODP) Leg 120 drilling on the Central Kerguelen Plateau was the presence of ice-rafted debris (IRD) in lowermost Oligocene nannofossil ooze at Site 748 (Figs. 1A and 1B), which lies at a present-day latitude of $58^{\circ} 26^{\prime} \mathrm{S}$ (Leg 120 Scientific Drilling Party, 1988). The initial discovery aboard ship was confirmed by shore-based scanning electron microscope (SEM) and microprobe study (Breza et al., 1988) and, as such, constituted the first unequivocal and documented evidence of Paleogene ice-rafting beyond the margins of the Antarctic continent. This physical evidence correlates remarkably well with stable isotopic and nannofossil evidence in the same cores of major cooling of ocean waters at this juncture (Zachos, this volume, Chapter 44; Wei et al., this volume, Chapter 55). The timing of the IRD event can be well established between 35.8 and 36.0 Ma by the excellent Cenozoic biostratigraphic and magnetostratigraphic record at this site (Inokuchi et al., this volume, Chapter 16; Berggren, this volume, Chapter 31; Wei et al., this volume, Chapter 55). This cooling was global and coincided with the initiation of the psychrosphere (Kennett and Shackleton, 1976), at least on a permanent basis.

\footnotetext{
${ }^{1}$ Wise, S. W., Jr., Schlich, R., et al., 1992. Proc. ODP, Sci. Results, 120 College Station, TX (Ocean Drilling Program).

${ }^{2}$ Department of Geology, Florida State University, Tallahassee, FL 32306, U.S.A.
}

This occurrence of pre-Miocene IRD on an isolated, submergent plateau $1000 \mathrm{~km}$ north of the Antarctic continent can be considered the "smoking gun" that demonstrates the presence of a significant ice sheet on the East Antarctic continent during the earliest Oligocene (Breza et al., 1988, 1989), a matter that has been the subject of considerable debate as discussed below. This new evidence bears directly on the question of the initiation and extent of Cenozoic glaciation of Antarctica, the duration and stability of the first continental ice sheet, and the nature of that ice sheet. In addition, this IRD and the sediments in which it is found have important implications for the paleoceanographic evolution of the water masses surrounding Antarctica.

In this paper we provide our complete documentation of early Oligocene ice-rafting at Site 748 and describe its paleoceanographic setting. In addition, we place this occurrence in the context of other published evidence for Oligocene continental glaciation of Antarctica and discuss this discovery in reference to the larger questions on Cenozoic glaciation of Antarctica and the development of high-latitude water masses posed above.

\section{PREVIOUS WORK}

\section{Reports of Paleogene Glacial and Glaciomarine Sediments in the Antarctic Region}

As summarized in Figure 2, the oldest reported Paleogene ice-rafted materials from the Southern Hemisphere deep-sea sediments are scattered quartz grains in nannofossil oozes 
A

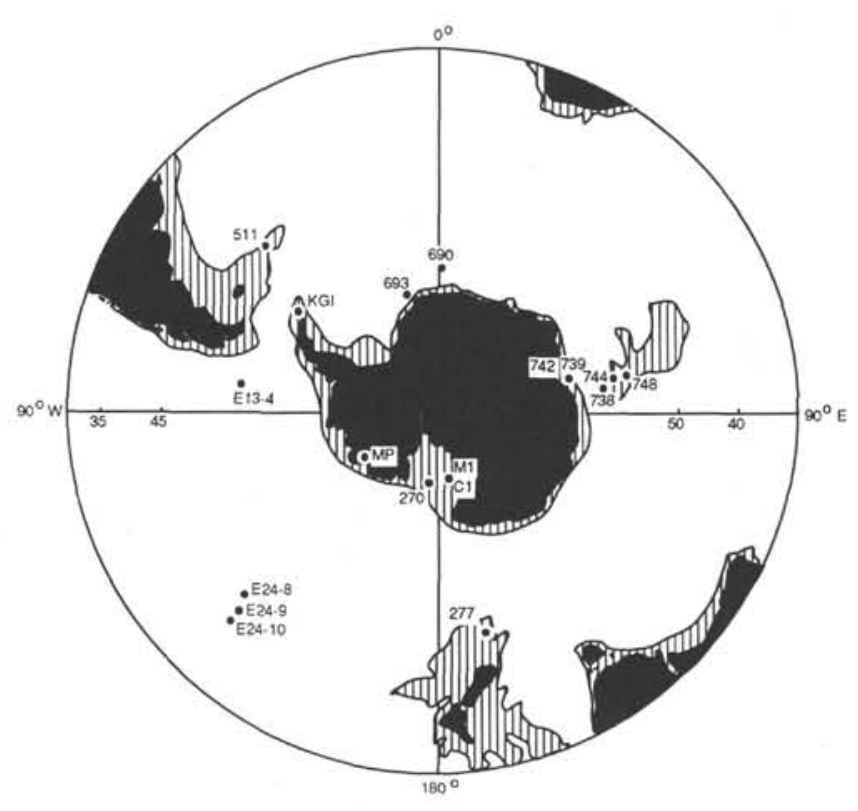

B

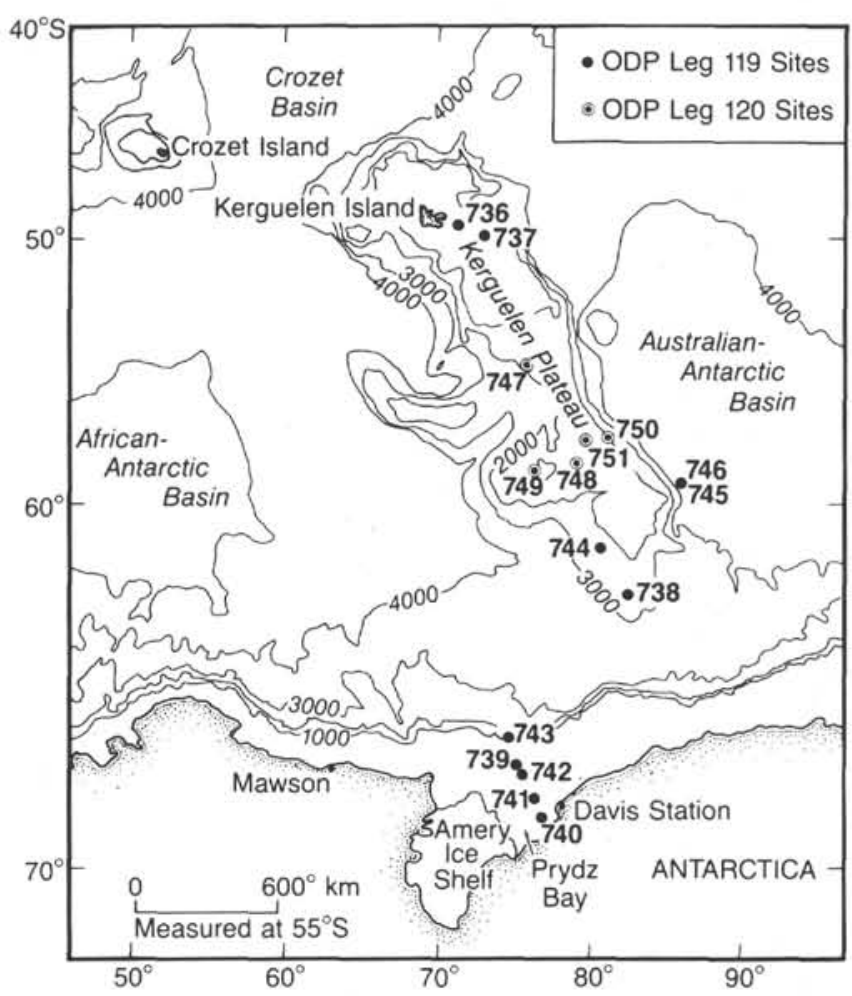

Figure 1. A. Location of Site 748, other ODP/DSDP drill sites (numbered), and sample localities discussed. KGI = King George Island and C1 = CIROS-1 drill core. B. Bathymetric chart of the Kerguelen Plateau showing the location of Site 748, other Leg 120 sites, and previously drilled Leg 119 sites in Prydz Bay.

reported by Margolis and Kennett (1971) from lower to middle Eocene piston cores taken by the Eltanin in the southeast Pacific Ocean at present-day latitudes between $38^{\circ}$ and $57^{\circ} \mathrm{S}$ (Fig. 1). The age assignment of these cores has been refined using nannofossil stratigraphy by Wei (this volume, Chapter 63). Birkenmajer et al. (1986) reported a tillite on King George Island (northern Antarctic Peninsula) beneath a lava flow dated at $49.4 \pm 5 \mathrm{Ma}$ (their "Krakow" glaciation). If confirmed, this could indicate a local alpine glacial source for the IRD reported by Margolis and Kennett (1971), as suggested by Wei (this volume, Chapter 63). No firm maximum age, however, has been established for these deposits. The glacial material contains reworked Cretaceous and Paleogene coccoliths, the youngest of which, according to Birkenmajer et al. (1988), are early Eocene in age. If documented, these latter specimens would provide a maximum age for the unit.

In addition to these presumed lower to middle Eocene tillites, the stable isotope record shows a major global cooling during the early middle Eocene (Shackleton and Kennett, 1975; Oberhänsli et al., 1984; Kennett and Stott, 1990) that may coincide with a major sea level drop (Vail et al., 1977; Haq et al., 1987). There is, however, some concern that the glacial material reported by Margolis and Kennett could be Quaternary contaminants introduced from the top of the sequences by the coring process, although Wei (this volume, Chapter 63) argues that this is unlikely, particularly for Eltanin Core 24-10, which apparently penetrated no Neogene sediment.

The first undisputed evidence of Paleogene glaciation on Antarctica was provided by Deep Sea Drilling Project (DSDP) Leg 28 drilling at Site 270 in the Ross Sea (Hayes, Frakes, et al., 1975), where upper Oligocene glaciomarine sediments were dated at $25 \mathrm{Ma}$. This is in harmony with suggestions by
LeMasurier and Rex $(1982,1983)$ of the presence of subglacial hyaloclastites in Marie Byrd Land dated at about $26 \mathrm{Ma}$.

Further drilling in the Ross Sea area recovered glacial sediments dated by Harwood et al. (1989) as 27 Ma (MISST-1 drill core) and as $36 \mathrm{Ma}$ (earliest Oligocene) and possibly older at the nearby CIROS-1 drill site (see also Wei, this volume, Chapter 64). The CIROS-1 cores provide the most complete record of Paleogene glacial activity yet recovered. The drill rig at the CIROS-1 site was located on present-day ephemeral sea ice, but the presence of lodgement tills at this site indicated that the Oligocene ice front extended at times well beyond that of the present day. The initial interpretation of the sequence suggested that the early Oligocene ice stemmed from valley glaciers along the Transantarctic Mountains and reached sea level, and that this alpine glaciation was followed in the late Oligocene by the full-scale development of an East Antarctic ice sheet (Barrett et al., 1987; in press). More recent interpretations, which take into account the preliminary Leg 119 and 120 drilling results and conclusions (Leg 119 Shipboard Scientific Party, 1988; Leg 120 Scientific Drilling Party, 1988), suggest that the early Oligocene ice was a manifestation of a "temperate" continental ice sheet that transcended the local mountain range (Barrett et al., 1989).

In the northern Antarctic Peninsula, Birkenmajer and Gazdzicki (1986) and Birkenmajer et al. (1986) obtained a $\mathrm{K} / \mathrm{Ar}$ radiometric date of more than $26.6 \mathrm{Ma}$ (probably 29.5 $\mathrm{Ma}$ ) on andesitic-dacitic lavas that overlie Paleogene glaciomarine sediments and tills believed to be of Oligocene age (Birkenmajer et al., 1988; Gazdzicki, 1989). Aside from the minimum age provided by the radiometric date, however, the age of this "Polenz glaciation" is derived from calcareous nannofossils and foraminifers within the sequence. Considerable confusion exists over the ages of these microfossils 


\begin{tabular}{|c|c|c|c|c|c|c|c|c|c|c|c|c|c|c|c|}
\hline \multirow{2}{*}{$\begin{array}{c}\text { Region } \\
\text { Site }\end{array}$} & \multicolumn{3}{|c|}{ Ross Sea } & \multirow{2}{*}{\begin{tabular}{|c|}
$\begin{array}{c}\text { Marie } \\
\text { Byrd Land }\end{array}$ \\
$\begin{array}{c}\text { Mh. } \\
\text { Petras * }\end{array}$ \\
\end{tabular}} & \multirow{2}{*}{$\begin{array}{c}\begin{array}{c}\text { Weddell } \\
\text { Sea }\end{array} \\
\text { ODP } \\
693^{5}\end{array}$} & \multicolumn{2}{|c|}{$\begin{array}{l}\text { Prydz } \\
\text { Bay: }\end{array}$} & \multicolumn{3}{|c|}{$\begin{array}{l}\text { Kerguelen } \\
\text { Plateau }\end{array}$} & \multirow{2}{*}{\begin{tabular}{|l|} 
Antarctic \\
Peninsula \\
King \\
George \\
Island
\end{tabular}} & \multicolumn{4}{|c|}{ Southeast Pacific ${ }^{10}$} \\
\hline & $\begin{array}{l}\text { DSDP, } \\
270\end{array}$ & MSSTS-12 & CIROS $-1^{3}$ & & & $\begin{array}{l}\text { ODP } \\
739\end{array}$ & $\begin{array}{l}\text { ODP } \\
742\end{array}$ & $\begin{array}{l}\text { ODP, } \\
738^{7}\end{array}$ & $\begin{array}{l}O D P \\
744^{7}\end{array}$ & $\begin{array}{l}\text { ODP } \\
748^{*}\end{array}$ & & $\begin{array}{c}\text { Eltanin } \\
13-4\end{array}$ & $\begin{array}{c}\text { Ehanin } \\
24-8\end{array}$ & $\begin{array}{c}\text { Elanin } \\
24-9\end{array}$ & $\begin{array}{l}\text { Ellanir } \\
24-10\end{array}$ \\
\hline Latitude & $77^{\circ} \mathrm{S}$ & $78^{\circ} \mathrm{S}$ & $77^{\circ} \mathrm{S}$ & $76^{\circ} \mathrm{S}$ & $71^{\circ} \mathrm{S}$ & $67^{\circ} \mathrm{S}$ & $67^{\circ} \mathrm{S}$ & $63^{\circ} \mathrm{S}$ & $62^{\circ} \mathrm{S}$ & $58^{\circ} \mathrm{S}$ & $62^{\circ} \mathrm{S}$ & $58^{\circ} \mathrm{S}$ & $43^{\circ} \mathrm{S}$ & $41^{\circ} \mathrm{S}$ & $38^{\circ} \mathrm{S}$ \\
\hline
\end{tabular}

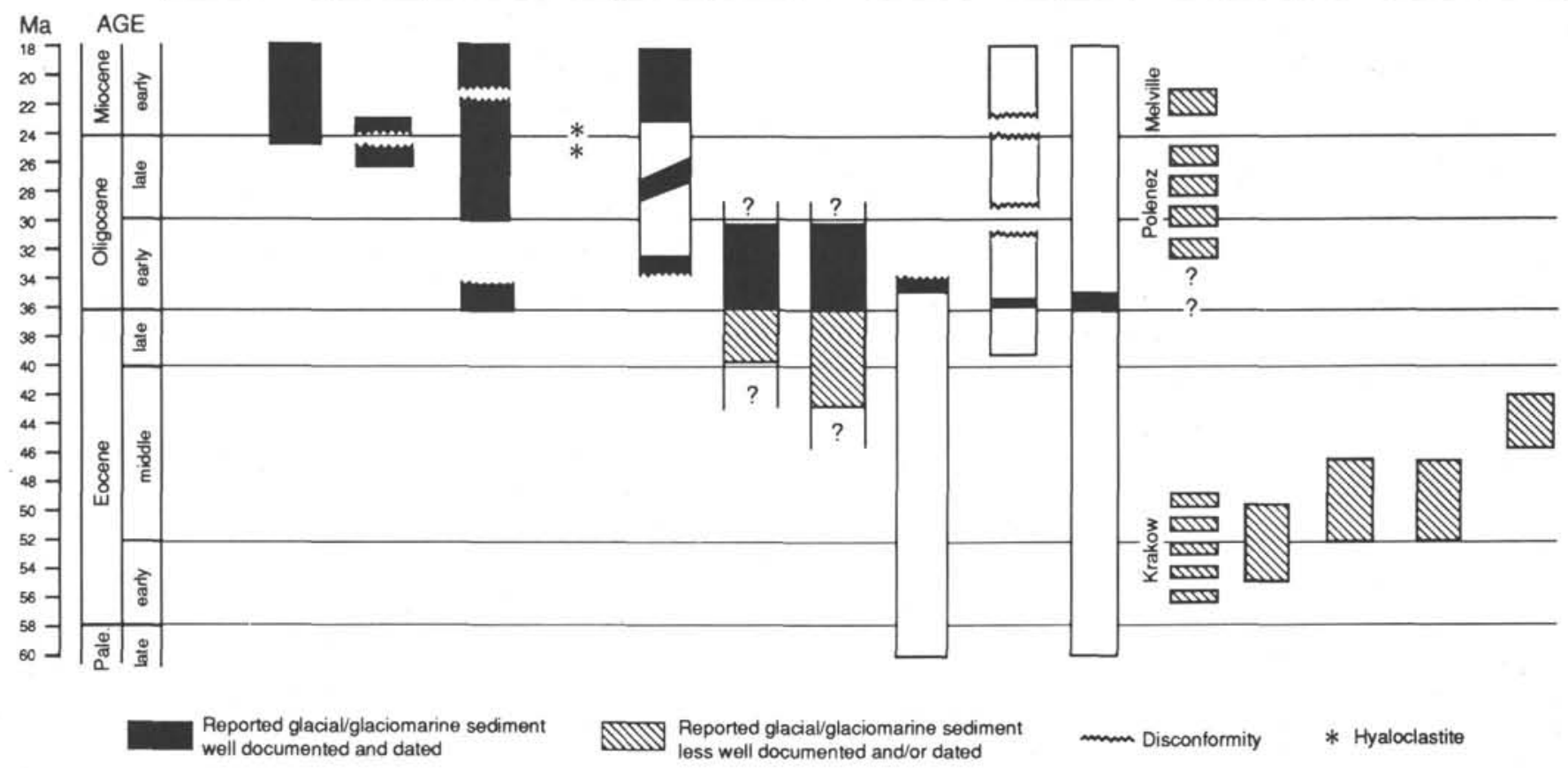

Figure 2. Occurrences of known or suspected Paleogene IRD, glaciomarine sediments or hyaloclastite (from Wise et al., 1991, and this volume, Chapter 56). 1 = Hayes, Frakes, et al. (1975); 2 = Barrett (1986), Harwood et al. (1989); 3 = Harwood et al. (1989); $4=$ LeMasurier and Rex (1982, 1983); 5 = Barker, Kennett, et al. (1988); 6 = Barron et al. (1991); 7 = Wei (this volume, Chapter 63); $8=$ Breza et al. (1988), this study; $9=$ Birkenmajer et al. (1988); $10=$ Wei (this volume, Chapter 63).

because all of the specimens well illustrated by SEM in their papers appear to have been reworked from the Eocene, including a chalk-encrusted foraminifer that has been illustrated in successive publications with contradictory interpretations as to its age (cf. Gazdzicka and Gazdzicki, 1985; Birkenmajer and Gazdzicki, 1986; Gadzicki, 1989). A middle Eocene age appears to be most likely for the specimen based on the presence of the nannofossil Chiasmolithus gigas. No convincing or definitive illustrations have been provided for microfossils interpreted to be Oligocene in age by Gazdzicka and Gazdzicki (1985) and by Birkenmajer et al. (1988).

In the Weddell Sea, Leg 113 drilling at Site 693 recovered a 47-m-thick sequence of Oligocene diatomaceous muds containing a minor percentage of ice-rafted sands and dropstones dated as $33 \mathrm{Ma}$. The base of this sequence is separated by a disconformity from middle Cretaceous sediments below (Barker, Kennett, et al., 1988). These deposits along the slope of the Antarctic continental margin (present-day water depth $=2359 \mathrm{~m}$ ), however, provide the first unequivocal evidence of Paleogene ice-rafting beyond the inland seas and shelves of Antarctica. Wise et al. (1987) interpreted this occurrence as evidence of the presence of an early Oligocene East Antarctic ice sheet. Kennett and Barker (1990), however, considered the evidence equivocal on this point and doubted the existence of a continental ice sheet.

The more recent drilling in Prydz Bay, Antarctica (Figs. 1A and 1B) by Leg 119 (Leg 119 Shipboard Scientific Party, 1988; Barron, Larsen, et al., 1989) encountered over $100 \mathrm{~m}$ of lower Oligocene diamictites interpreted as lodgement tills and glaciomarine sediments deposited at sea level. Below these are additional diamictites, which, according to shipboard magnetostratigraphy, could be late Eocene to latest middle Eocene in age. The areal extent and overcompacted nature of these sediments indicate that grounded ice in the past extended at least $140 \mathrm{~km}$ beyond the limits of the present ice shelf. This convinced Leg 119 scientists that full-scale ice-sheet development had taken place over East Antarctica by at least early Oligocene time (Leg 119 Shipboard Scientific Party, 1988). In addition, these scientists encountered lower Oligocene quartz sands and granules at Sites 738 and 744 on the Southern Kerguelen Plateau (Fig. 1B), some or all of which they speculated could have been ice-rafted from East Antarctica, West Antarctica, or from islands on the plateau itself (Barron, Larsen, et al., 1989).

\section{Stable Isotope and Other Evidence for Paleogene Glacial Activity}

Often cited in conjunction with the interpretations of ice-rafted or glaciomarine sediments are stable isotope studies of Paleogene foraminifers from the world's oceans. As indirect, "proxy" evidence for climate change gathered in regions beyond the Antarctic continent, this line of investigation has historically resulted in the widest range of opinions over the presence or absence of an early Oligocene ice sheet on the continent. The interpretation of the isotope records relies on a number of assumptions, not all of which are universally agreed upon (see review by Harwood et al., in press, and discussion below).

Immediately following the discovery of upper Oligocene diamictites in the Ross Sea, DSDP Leg 29 recovered a long 
Paleogene carbonate section at Site 277 to the north on the Campbell Plateau (Fig. 1A) that provided the first extensive stable isotopic records from the deep sea. A major positive $\delta^{18} \mathrm{O}$ excursion close to the Eocene/Oligocene boundary in that sequence was attributed by Shackleton and Kennett (1975; see also Kennett and Shackleton, 1976; Kennett, 1978) to the beginning of significant sea-ice formation around Antarctica but not to the formation of an ice sheet on Antarctica. They extrapolated a surface-water temperature of about $\mathrm{O}^{\circ} \mathrm{C}$ for waters along the margins of Antarctica and suggested that such an ice sheet did not form until middle Miocene time, in agreement with Savin et al. (1975), who studied a tropical Pacific isotopic record. Calculating paleotemperatures for an "ice-free" Oligocene world, both groups suggested that the early Oligocene oceanic temperatures were comparable with those of the present day at the sites investigated, but Savin et al. (1975) and Savin (1977) considered the values in the tropical Pacific as too warm for the formation of sea ice around Antarctica.

Matthews and Poore (1980), however, concluded that paleotemperature scales calibrated for an "ice-free world" produced unreasonably low Paleogene tropical sea-surface temperatures, and that in all probability, the earth had been glaciated since at least the Eocene. They assumed a significant ice-volume effect on Paleogene $\delta^{18} \mathrm{O}$ values (Poore and Matthews, 1984; Prentice and Matthews, 1988). Poore and Matthews (1984) concluded that the isotopic temperatures for the early Oligocene recorded not only an ice-volume effect, but that surface-water values in the high southern latitudes were influenced by low salinities as well.

With the study of additional deep-sea drill sections, other investigators agreed at least in part with some of the interpretations of Matthews and his colleagues, at least for the Oligocene (Miller and Fairbanks, 1983; Keigwin and Keller, 1984; Shackleton et al., 1984; Miller and Thomas, 1985; Wise et al., 1985; Keigwin and Corliss, 1986; Miller et al., 1987; Zachos et al., this volume). Investigators have not agreed, however, on the magnitude of the ice-volume correction for the early Oligocene isotopic paleotemperatures (or by inference the size and nature of the Antarctic ice sheet at that time) or whether an ice sheet was present on Antarctica during the Eocene.

Other lines of evidence sought on this question include studies of reworked Cenozoic microfossils in late Neogene tills of the Sirius Group, a series of glacial deposits in the Transantarctic Mountains. Webb et al. (1984) believe that such fossils were eroded from intracratonic marine basins now buried beneath the East Antarctic Ice Sheet. The reworked fossils would indicate times when the basins were ice free, and their absence would imply times when the basins were occupied by ice. On this basis, Webb et al. (1984) and Harwood et al. (in press; see additional references therein) concluded that an ice sheet was present over East Antarctica during latest Eocene-earliest Oligocene time.

In view of the wide range of opinions over the development of Cenozoic glaciation of Antarctica, and the importance of this history toward understanding the evolution of global climates over the past $50 \mathrm{~m}$.y., there has clearly been a need for more direct evidence of glacial activity on Antarctica. It was partly in search of such data that ODP undertook the recent series of cruises to the Southern Ocean, beginning with Leg 113 and culminating with Leg 120.

\section{GEOLOGIC SETTING}

Hole 748B was drilled on the Central Kerguelen Plateau in the western part of the Raggatt Basin, east of Banzare Bank. The geographic isolation of the Kerguelen Plateau provides an ideal setting to study IRD records in this part of the Southern Ocean. The plateau is a structural high isolated from any continental input by means of turbidites or nepheloid transport (Fig. 1B). It is bounded to the northeast by the Australian-Antarctic Basin, to the southwest by the African-Antarctic Basin, and to the northwest by the Crozet Basin. To the south it is separated from Antarctica by the Princess Elizabeth Trough. This isolation makes it probable that any nonvolcanic clastic debris found in the sediments at this site would be of ice-rafted origin.

The physiographic setting of the Kerguelen Plateau is somewhat similar to that of the eastern Falkland Plateau. Both plateaus are submerged aseismic structural highs far removed from any direct continental influence. In his study of IRD on the Maurice Ewing Bank of the Falkland Plateau, Bornhold (1983) was able to exclude the effects of transportation of clastic material by wind, turbidites, and bottom-water currents based on the physiographic make-up of the plateau. Similarly, the isolation of the Kerguelen Plateau controls many of the variables of terrigenous sedimentation that would otherwise hide or skew an IRD record. Thus, in this study we consider all clastic sands and any pebbles not of volcanic origin to be products of ice-rafting.

\section{CORE DESCRIPTION}

Clastic materials, interpreted to be IRD (see "Discussion" section, this chapter), were encountered in Sections 120$748 \mathrm{~B}-14 \mathrm{H}-1$ and -2 between 115.45 and $115.77 \mathrm{~m}$ below sea floor (mbsf). Core 120-748B-14H is composed of nannofossil ooze with siliceous microfossils and foraminifers (Fig. 3). The nannofossil ooze is white $(5 \mathrm{Y} 8 / 1)$ with light gray $(5 \mathrm{Y} 7 / 1)$ and bluish gray $(5 \mathrm{~B} 6 / 1)$ laminations $(1-10 \mathrm{~mm})$. There is a marked increase in the biosiliceous component in the interval containing the IRD (approximately $27 \%$ siliceous microfossils), which is light greenish gray (5G 7/1) and occurs between Sections $120-748 \mathrm{~B}-14 \mathrm{H}-1,137-150 \mathrm{~cm}$, and $-2,0-24 \mathrm{~cm}$ (Figs. 3 and 4). As such, this sediment is classified as a siliceous nannofossil ooze, the only example of this lithology in the entire Paleogene section at this site (Schlich, Wise, et al., 1989, p. 454). The contact between this minor lithology and the underlying nannofossil ooze is sharp and readily distinguishable. Below this contact, the siliceous ooze has been bioturbated over a distance of $18 \mathrm{~cm}$ down into the underlying nannofossil ooze (Fig. 4). Based on shipboard examination of the core, there is no increase in grain size of the biogenic matrix; therefore, we do not consider the material to be a lag deposit (Schlich, Wise, et al., 1989).

\section{METHODS \\ Spatial Sampling Strategy}

We collected 15 samples from the interval of lower Oligocene nannofossil ooze between 114.77 and $116.62 \mathrm{mbsf}$ in Sections 120-748B-14H-1 and -2. Samples collected between 115.47 and 115.96 mbsf were spaced at an average of $5.4 \mathrm{~cm}$. Based on shipboard-derived sedimentation rates $(0.63 \mathrm{~cm} /$ k.y.), the sampling frequency $(5.4-\mathrm{cm}$ intervals) represents a resolution of approximately $8,600 \mathrm{yr}$. This sampling frequency is intended to provide a high resolution coverage that will allow detailed documentation of the early Oligocene icerafting, and to supply sufficient data to determine whether the rafting was a single or multiple event.

\section{Laboratory Techniques}

Samples were disaggregated by soaking them in distilled water for $24 \mathrm{hr}$. They were then dried, weighed, and washed through $250-$ and $62.5-\mu \mathrm{m}$ sieves using distilled water. The 


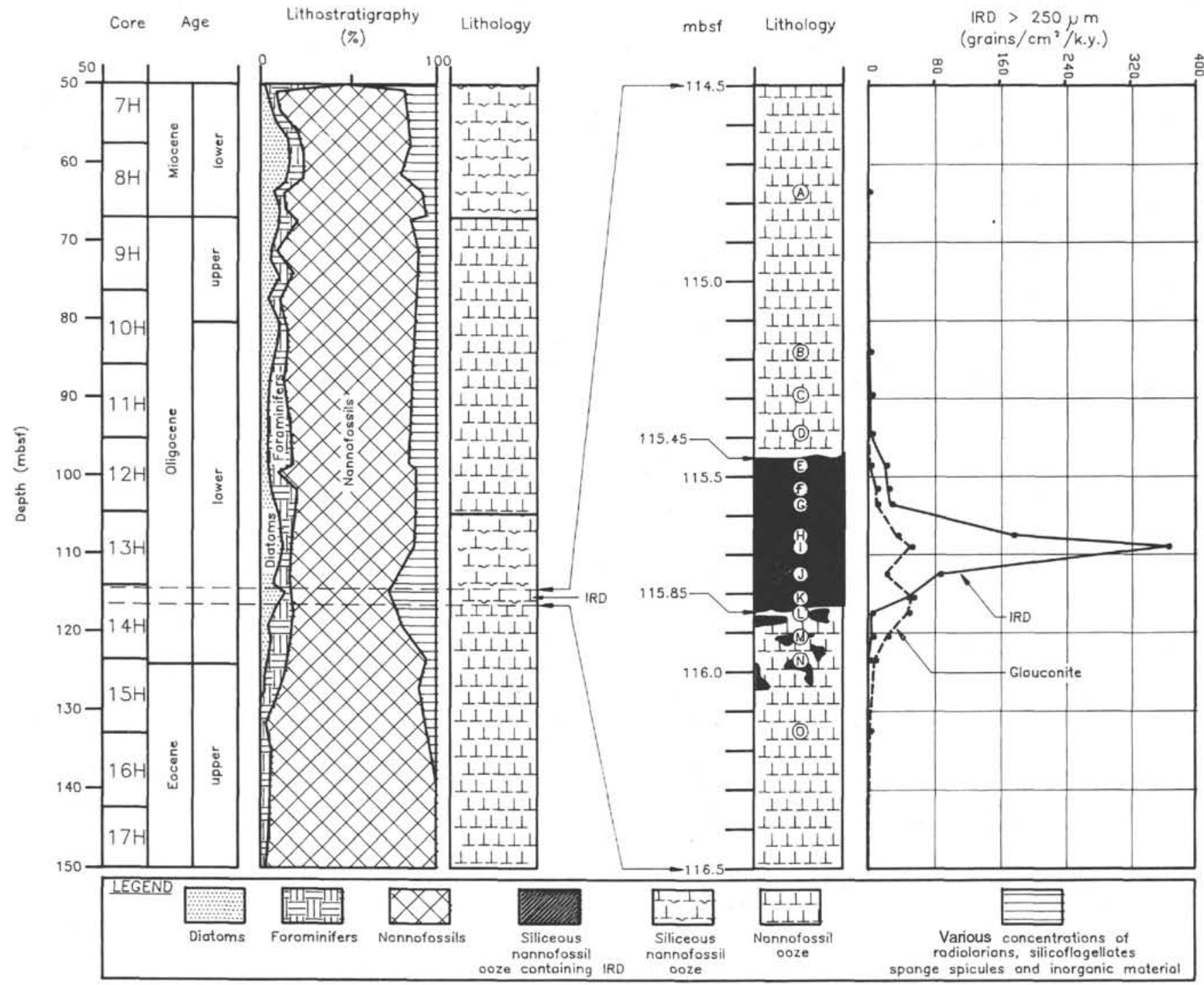

Figure 3. Site 748B lithostratigraphic summary for the interval between 50 and 150 meters below sea floor ( $\mathrm{mbsf}$ ). Inset is an enlargement of the lower Oligocene section containing ice-rafted debris (IRD). The graph clearly shows the vertical extent of the ice-rafted event and its apparent accumulation rates for ice-rafted debris and glauconite grains. Letters A through $\mathrm{O}$ noted in the lithology column correspond to the sample identification number: $\mathrm{A}=120-748 \mathrm{~B}-14 \mathrm{H}-1,65-69 \mathrm{~cm} ; \mathrm{B}=120-748 \mathrm{~B}-14 \mathrm{H}-1,106-109 \mathrm{~cm} ; \mathrm{C}=120-748 \mathrm{~B}-14 \mathrm{H}-1,118-119 \mathrm{~cm} ; \mathrm{D}=$ $120-748 \mathrm{~B}-14 \mathrm{H}-1,128-129 \mathrm{~cm} ; \mathrm{E}=120-748 \mathrm{~B}-14 \mathrm{H}-1,135-139 \mathrm{~cm} ; \mathrm{F}=120-748 \mathrm{~B}-14 \mathrm{H}-1,142-143 \mathrm{~cm} ; \mathrm{G}=120-748 \mathrm{~B}-14 \mathrm{H}-1,145-149 \mathrm{~cm} ; \mathrm{H}=$ $120-748 \mathrm{~B}-14 \mathrm{H}-2,4-5 \mathrm{~cm} ; \mathrm{I}=120-748 \mathrm{~B}-14 \mathrm{H}-2,7-9 \mathrm{~cm} ; \mathrm{J}=120-748 \mathrm{~B}-14 \mathrm{H}-2,14-15 \mathrm{~cm} ; \mathrm{K}=120-748 \mathrm{~B}-14 \mathrm{H}-2,20-21 \mathrm{~cm} ; \mathrm{L}=120-748 \mathrm{~B}-14 \mathrm{H}-2$, $24-26 \mathrm{~cm} ; \mathrm{M}=120-748 \mathrm{~B}-14 \mathrm{H}-2,30-31 \mathrm{~cm} ; \mathrm{N}=120-748 \mathrm{~B}-14 \mathrm{H}-2,35-39 \mathrm{~cm}$; and $\mathrm{O}=120-748 \mathrm{~B}-14 \mathrm{H}-2,54-56 \mathrm{~cm}$.

$<62.5-\mu \mathrm{m}$ size fraction was reserved for X-ray diffraction (XRD) analysis of the clay-sized material. Each sieved sand fraction was then dried and weighed. The pebble-sized fraction ( $\geq 2 \mathrm{~mm}$ ) was measured and described. The composition of the medium to very coarse fraction $(\geq 250 \mu \mathrm{m}$ to $<2$ $\mathrm{mm}$ ) was examined under binocular and petrographic microscopes, and all clastic and authigenic components were identified and counted. The biogenic components of this size fraction were not analyzed. Clastic, authigenic, and biogenic components in the very fine to fine fractions $(\geq 62.5$ to $<250$ $\mu \mathrm{m})$ were not analyzed. Clastic components were grouped into four categories: quartz, feldspar, heavy minerals, and rock fragments. Glauconite, the only authigenic component identified, was grouped as such and excluded from the clastic material. Total clastic components $\geq 250 \mu \mathrm{m}$ were normalized to the total dry-bulk weight of the sample (number of grains per gram). Normalization was also performed on glauconite.

A JEOL-840 scanning electron microscope (SEM) with a KEVEX Delta energy-dispersive X-ray (EDX) system was used to produce the SEM micrographs and EDX spectrums. Samples for SEM analysis only were coated with gold (Au) and palladium (Pd). Samples analyzed by the EDX were coated with carbon except the specimen in Figure 6, which had already been coated with Au-Pd.

After processing, the unwashed portions of the closely spaced samples described above were sent to James Zachos so that he could perform the stable isotope analyses on the same samples. Those results are reported in Zachos et al. (this volume, Chapter 44). 


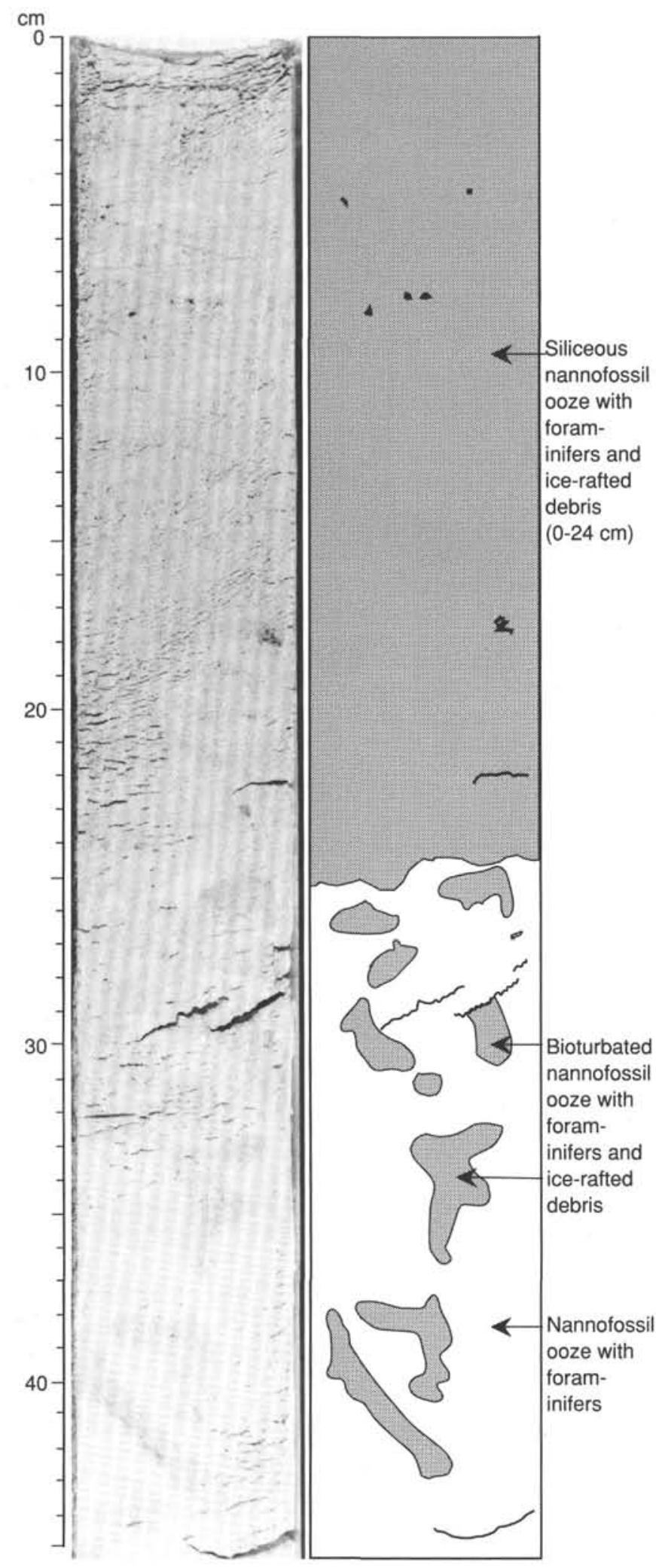

Figure 4. Siliceous nannofossil ooze (shaded) containing sand-size ice-rafted debris of earliest Oligocene age in Section 120-748B-14H-2, $0-24 \mathrm{~cm}$. This layer has been bioturbated into the underlying nannofossil ooze (Section 120-748B-14H-2, 25-45 cm); from Schlich, Wise, et al. (1989, p. 174, fig. 13).

\section{Ice-rafting Index}

The $\geq 250$ - $\mu \mathrm{m}$-diameter clastic fraction was selected as the ice-rafting event index. As discussed in more detail below (see "Discussion" section, this chapter), we interpret this size fraction as being of ice-rafted origin because (1) the presence of windblown material $>250-\mu \mathrm{m}$ in diameter at any appreciable distance from a source area is unlikely (Kent et al., 1971), and (2) transport of this size material by turbidity flow is not considered a factor because of the relatively shallow depths of this oceanic drill site and the isolated location of the Kerguelen Plateau. The most commonly used method to derive an ice-rafted index or to determine the distribution of IRD for the very fine to fine sand fraction $(\geq 62.5 \mu \mathrm{m}$ to $<250 \mu \mathrm{m})$ is either to calculate the weight percent of the total clastic components or to calculate the percentage of clastic components from a point count of a set number of grains (Kent et al., 1971; Margolis and Kennett, 1971; Keany et al., 1976; Bornhold, 1983; Anderson, 1985). However, our study uses a different method, as described by Kennett and Brunner (1973), to determine the ice-rafted index; that is, counting the entire suite of clastic grains present in the medium to very coarse sand fraction ( $\geq 250 \mu \mathrm{m}$ to $<2 \mathrm{~mm}$ ) to calculate the number of grains per gram.

\section{IRD Apparent Accumulation Rate}

The IRD index is adjusted for sedimentation rates and density contrast between constituents to provide an approximate accumulation rate of the IRD. The apparent accumulation rate equation used in this study was modified from Keany et al. (1976). Keany et al. (1976) use the term "apparent" to reflect possible natural processes that may distort the measured accumulation rates, such as subtle, undefinable changes in sedimentation rate and large contrasts in density between constituents. The IRD rate was computed by using the equation:

$$
R=N / D \times S,
$$

where $R=$ apparent accumulation rate,

$N=$ number of grains per gram of dry-bulk sample,

$D=$ dry-bulk density, and

$S=$ sedimentation rate.

The apparent accumulation rate is expressed as grains per square centimeter per $1000 \mathrm{yr}$.

This method of calculating apparent accumulation rates has the following advantages: (1) it overcomes most of the distortion inherent in presenting data in the percentage format, and (2) it incorporates changes in sedimentation rates that can either dilute or concentrate the occurrence of IRD. Dry-bulk density values and sedimentation rates used in this study were obtained from Schlich, Wise, et al. (1989). Dry-bulk density values were derived by averaging the two closest dry-bulk density measurements taken above and below the IRD interval, at 114.44 and 115.75 mbsf, respectively. Calculations of apparent accumulation rates in this study assume that drybulk density and sedimentation rates were constant throughout the interval being analyzed.

\section{RESULTS}

The clastic constituents within the interval in question are predominantly fine to coarse sand, composed of three kinds of quartz: (1) gray and translucent, (2) milky, and (3) clear, with inclusions. Other minerals found in this interval are altered feldspars, yellowish to brown feldspars, minor amounts of 
heavy minerals, and glauconite. Volcanic ash was not detected within the interval.

The first occurrence of clastic material in the lower Oligocene was observed in Sample 120-748B-14H-2, 35-39 cm, at 115.97 mbsf. The last occurrence was observed in Sample 120-748B$14 \mathrm{H}-1,106-110 \mathrm{~cm}$, at $115.18 \mathrm{mbsf}$ (Fig. 3 and Table 1).

\section{Quartz Grains}

The quartz grains are generally subangular to highly angular, with few subrounded grains (Fig. 5). Quartz grain abundance is $83 \%-100 \%$ of the total clastic component. The greatest occurrence of quartz was observed in Sample 120. 748B-14H-2, 7-9 cm (155.68 mbsl), with 2161 grains or 228 grains/g (Table 1). The quartz was coarse enough to be detected during the preparation of standard smear slides as the large grains hindered mounting of the cover glasses.

The SEM examination of surface textures on quartz grains shows a variety of fresh fracture features, as illustrated in Figure 5. The observed features include smooth, dish-shaped, conchoidal fractures (Figs. 5A-5C); arc-shaped, steplike fractures (Figs. 5C-5E); blocky surface features (Fig. 5C); and sharp angular outlines and medium to high relief (Figs. 5A and $5 \mathrm{C})$. The most common surface textures observed in the samples are arc-shaped, steplike fractures and dish-shaped, conchoidal fractures. These surface textures are considered to be diagnostic of glacially worked grains, according to Krinsley and Donahue (1968), Margolis and Kennett (1971), and Margolis and Krinsley (1974).

\section{Heavy Mineral Grains}

Six heavy minerals among the clastic constituents (garnet, hornblende, ilmenite, mica, rutile, and tourmaline) were identified using the petrographic and binocular microscopes. Heavy mineral abundance is highest in Sample 120-748B-2H, 4-5 and $7-9 \mathrm{~cm}$, at concentrations of 3 and 4 grains $/ \mathrm{g}$, respectively.

Several heavy mineral grains identified by light microscopy in Sample 120-748B-2H, 7-9 cm, were examined by SEM and qualitative energy-disperive X-ray (EDX), and these results support the optical identifications (Figs. 6-8). For instance, the EDX spectra for the rounded ilmenite grain in Figure 6 yields strong titanium and iron peaks, whereas the garnet grain in Figure 7 contains calcium, iron, and aluminum. The hornblende grain in Figure 8 displays characteristic $120^{\circ}$ and $60^{\circ}$ cleavage patterns, and the corresponding EDX analysis indicates the presence of calcium and iron. Overall, the heavy mineral suite observed in the clastic debris interval is characteristic of metamorphic and/or plutonic rock sources.

\section{Pebble-sized, Ice-rafted Debris}

Sample 120-748B-14H-2, 7-9 cm, contained five quartz pebbles or granules ranging in size from 2 to $3.5 \mathrm{~mm}$ (Table 2). The pebbles are subrounded to subangular and are clear to gray and translucent. In addition, the $1-\mathrm{cm}$ rock fragment was recovered in Sample 120-748B-14H-1, 9-10 cm (J. Zachos, pers. comm., 1989), but upon reexamination of the core, this proved to be a downhole contaminant (see "Discussion" section, this chapter).

\section{Glauconite Grains}

Glauconite grains of various degrees of maturity are present at moderate concentrations. This material was not classified as clastic debris because its origin is uncertain. It may have formed in situ or may have been transported to the site. The glauconite is green to blackish green.

The first occurrence of glauconite was observed in Sample $120-748 \mathrm{~B}-14 \mathrm{H}-2,54-56 \mathrm{~cm}$ (Tables 1 and 3). The last occurrence was observed in Sample 120-748B-14H-1, 106$110 \mathrm{~cm}$. Glauconite concentrations are low relative to the clastic material and fluctuate throughout the entire interval. Two minor peaks of glauconite concentrations were observed (Fig. 3). The first peak occurs at the base of the clastic debris interval with concentration of 25 and 28 grains/g in Samples 120-748B-14H-2, 24-26 and 20-21 cm, respectively. The second glauconite peak ( 27 grains $/ g$ ) coincides with the maximum clastic debris peak of 268 grains/g at 115.68 mbsf.

\section{Ichthyoliths}

Ichthyoliths, or fish skeletal debris, were found in Samples $120-748 \mathrm{~B}-14 \mathrm{H}-2,20-21 \mathrm{~cm}$, and $-14 \mathrm{H}-2,30-31 \mathrm{~cm}$, at concentrations of 7.5 and 3.1 grains $/ \mathrm{g}$, respectively. The ichthyolith fragments occur at the base of the IRD interval. These range in size from $>250 \mu \mathrm{m}$ to $1.5 \mathrm{~mm}$, and are reddish brown in color and slightly translucent. Viewed through a petrographic microscope, the fragments exhibit optical properties characteristic of apatite.

Table 1. Composition of Site 748B lower Oligocene ice-rafted debris and glauconite grains ( $\geq 250 \mu \mathrm{m})$.

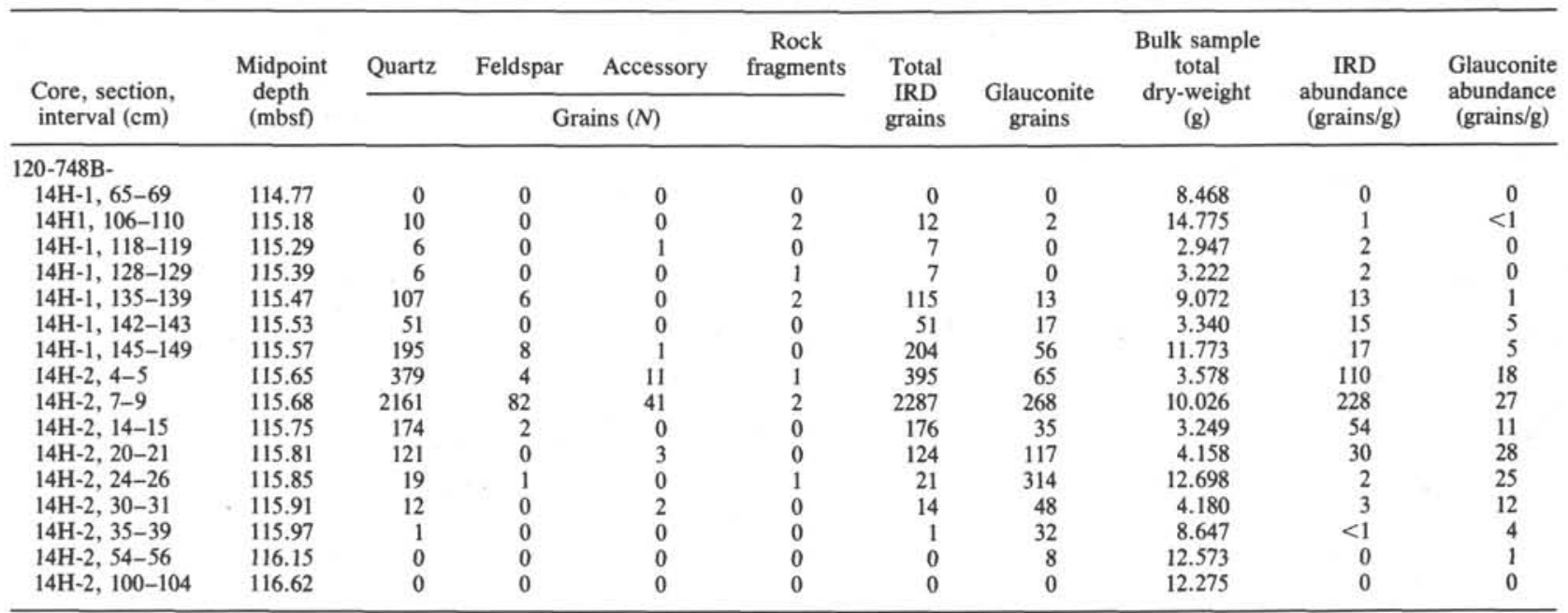

Notes: Total ice-rafted debris and glauconite concentrations have been normalized to grains/g of total dry weight of bulk sample. Accessory minerals included some, if not all, of the following minerals: garnet, hornblende, ilmenite, mica, rutile, and tourmaline. 


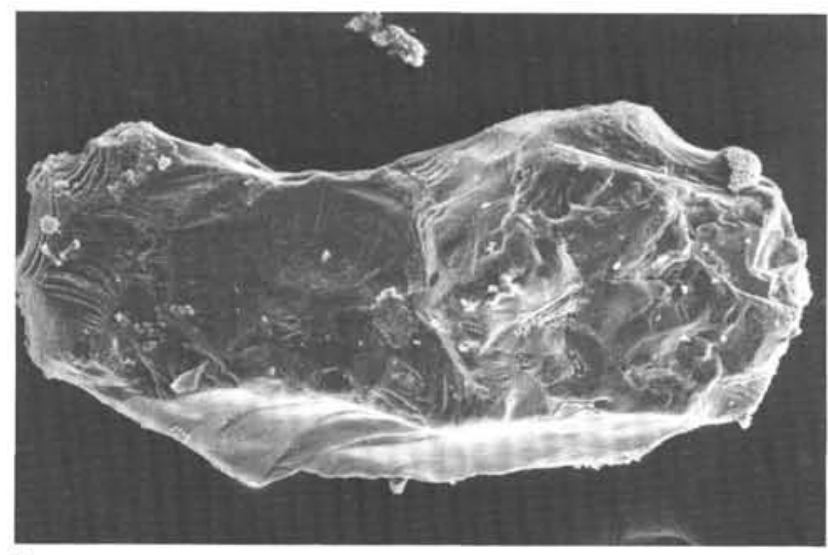

A

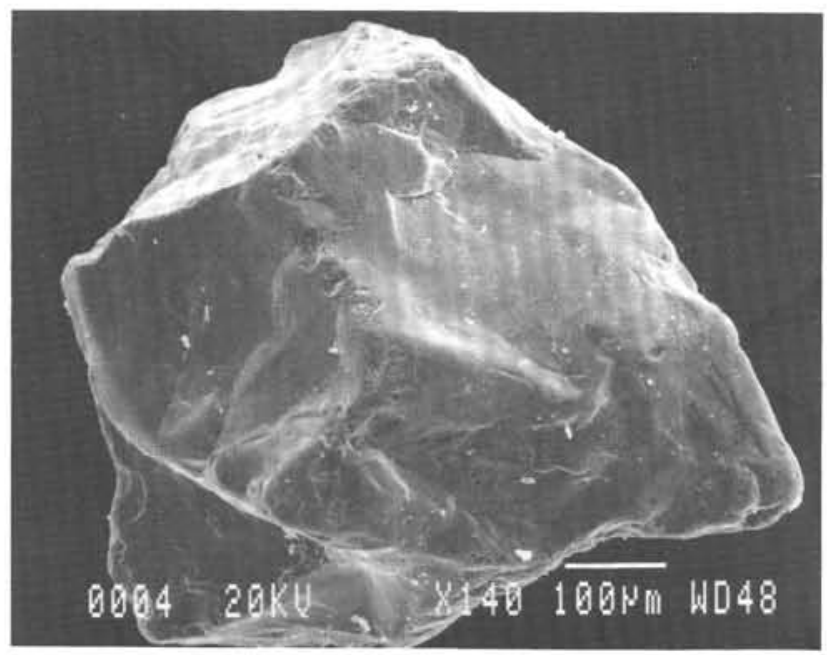

C

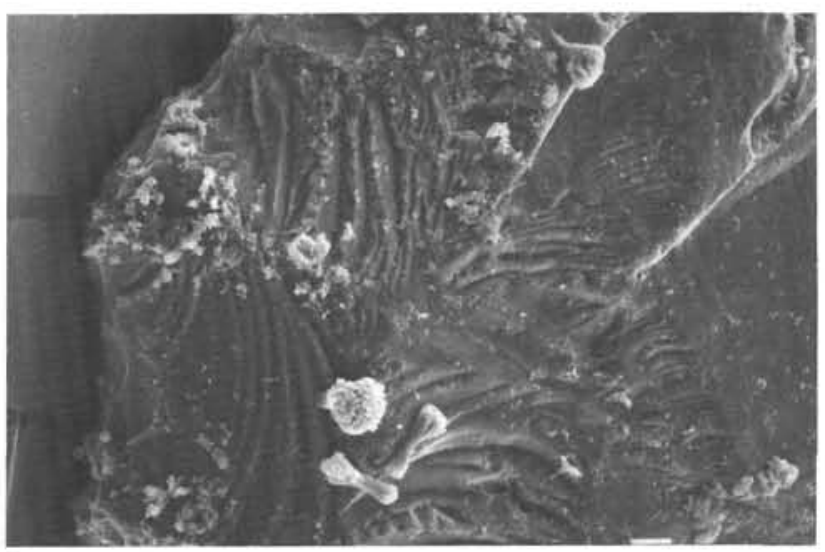

B

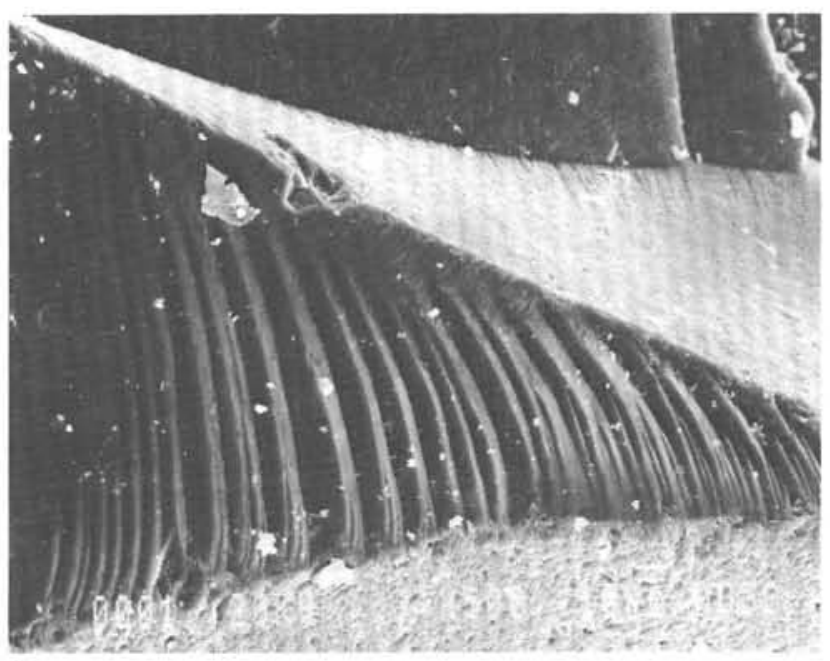

D

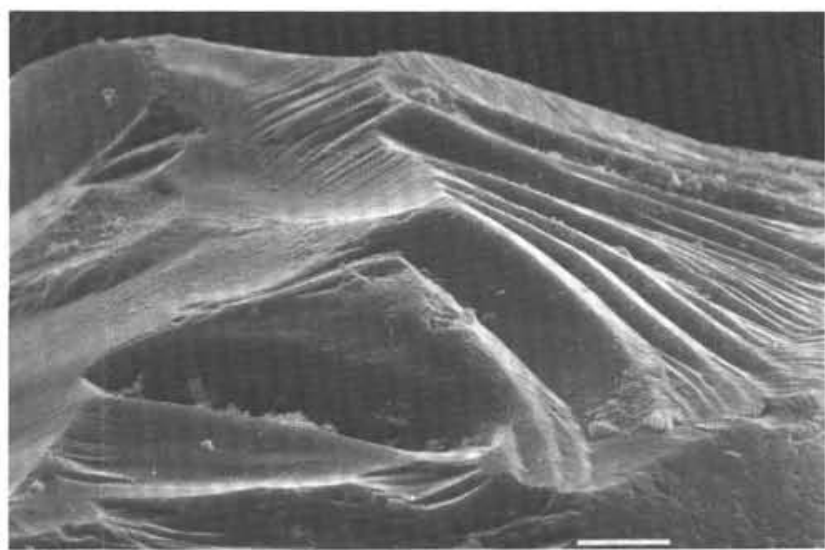

E

Figure 5. Scanning electron micrograph (SEM) of quartz grains. A. SEM of quartz grain showing sharp angular outline, medium relief, and smooth dish-shaped conchoidal fractures. Sample 120-748B-14H-2, 7-9 cm, $\times 97.5$. B. SEM close-up of the grain in Figure 5A. Sample 120-748B-14H-2, 7-9 cm, $\times 315$. C. Angular quartz grain showing medium relief, arc-shaped, steplike fractures, smooth dish-shaped conchoidal fractures, and blocky surface features. Sample 120-748B$14 \mathrm{H}-1,135-139 \mathrm{~cm}, \times 80$. D. Arc-shaped, steplike fractures bounded above and below by etch pits along the unbroken grain surface. Sample 120-748B-14H-2, 7-9 cm, $\times 285$. E. Arc-shaped, steplike fractures. Sample 120-748B-14H-1, 145-149 cm, $\times 750$. 

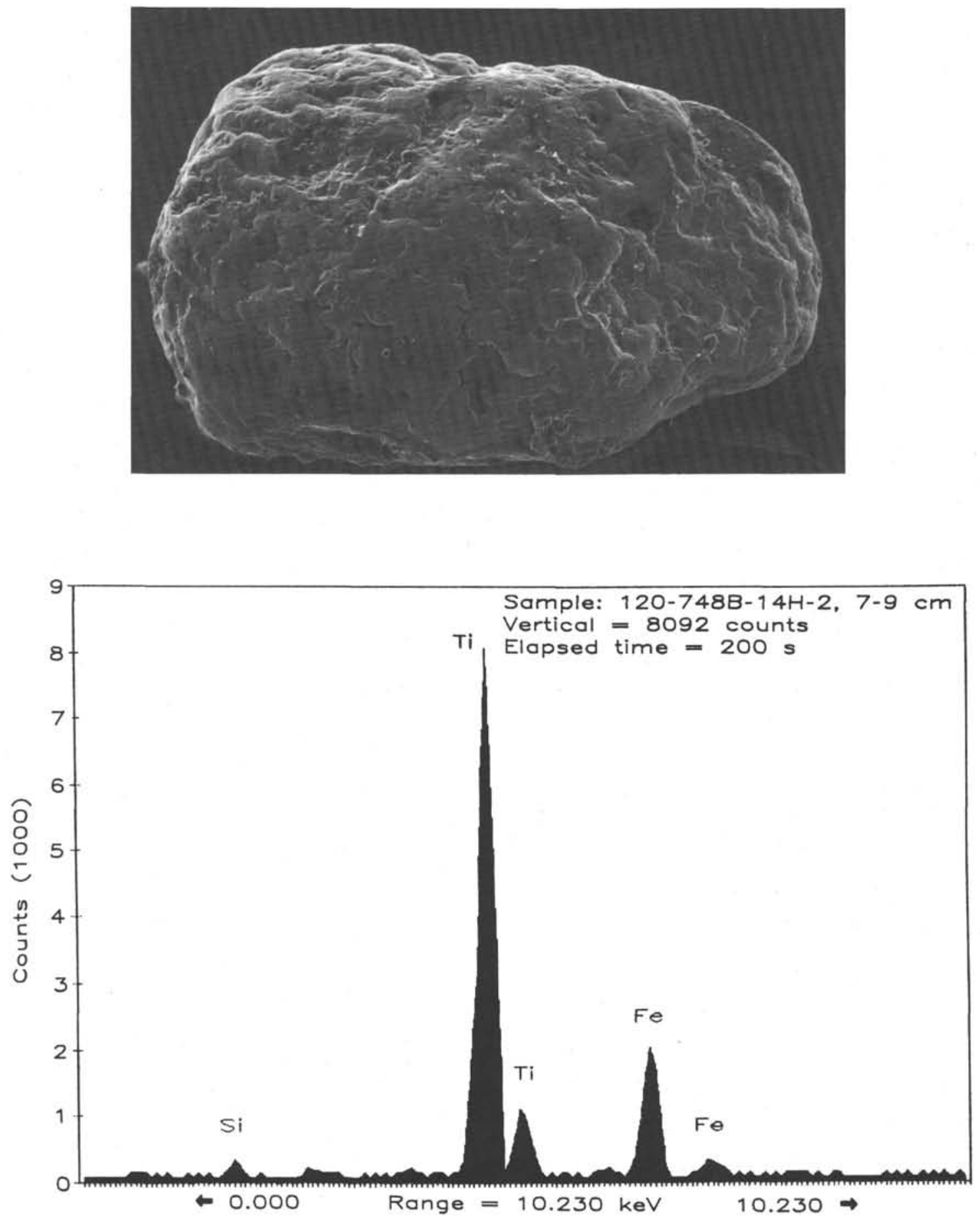

Figure 6. Scanning electron micrograph of porous, rounded ilmenite grain. The elements displayed on the qualitative EDX spectrum are consistent with those given in the formula for this mineral $\left(\mathrm{FeTiO}_{3}\right)$. Sample 120-748B-14H-2, 7-9 $\mathrm{cm}, \times 150$.

\section{Apparent Accumulation Rates of the Clastic Detritus (IRD)}

Distribution of the clastic detritus is leptokurtic with concentrations skewed upcore (Fig. 3). The first appearance of clastic material is in Sample $120-748 \mathrm{~B}-14 \mathrm{H}-2,30-31 \mathrm{~cm}$ (115.91 mbsf). The IRD concentrations do not exceed 5 grains $/ \mathrm{cm}^{2} / \mathrm{k}$.y. between 115.91 and $115.47 \mathrm{mbsf}$, as shown in
Table 3. Elevated IRD apparent accumulation rates extend from 115.81 to $115.57 \mathrm{mbsf}$ and average 141 grains $/ \mathrm{cm}^{2} / \mathrm{k}$.y. This interval contains the greatest concentration of IRD, with an apparent accumulation rate of 366 grains $/ \mathrm{cm}^{2} / \mathrm{k} . \mathrm{y}$. at 115.68 mbsf. At $11 \mathrm{~cm}$ above the maximum IRD peak, the apparent accumulation rates decline to 27 grains $/ \mathrm{cm}^{2} / \mathrm{k}$.y. at 115.57 mbsf. The last occurrence of IRD is found in Sample 120748B-14H-1, 106-109 cm (115.18 mbsf). 

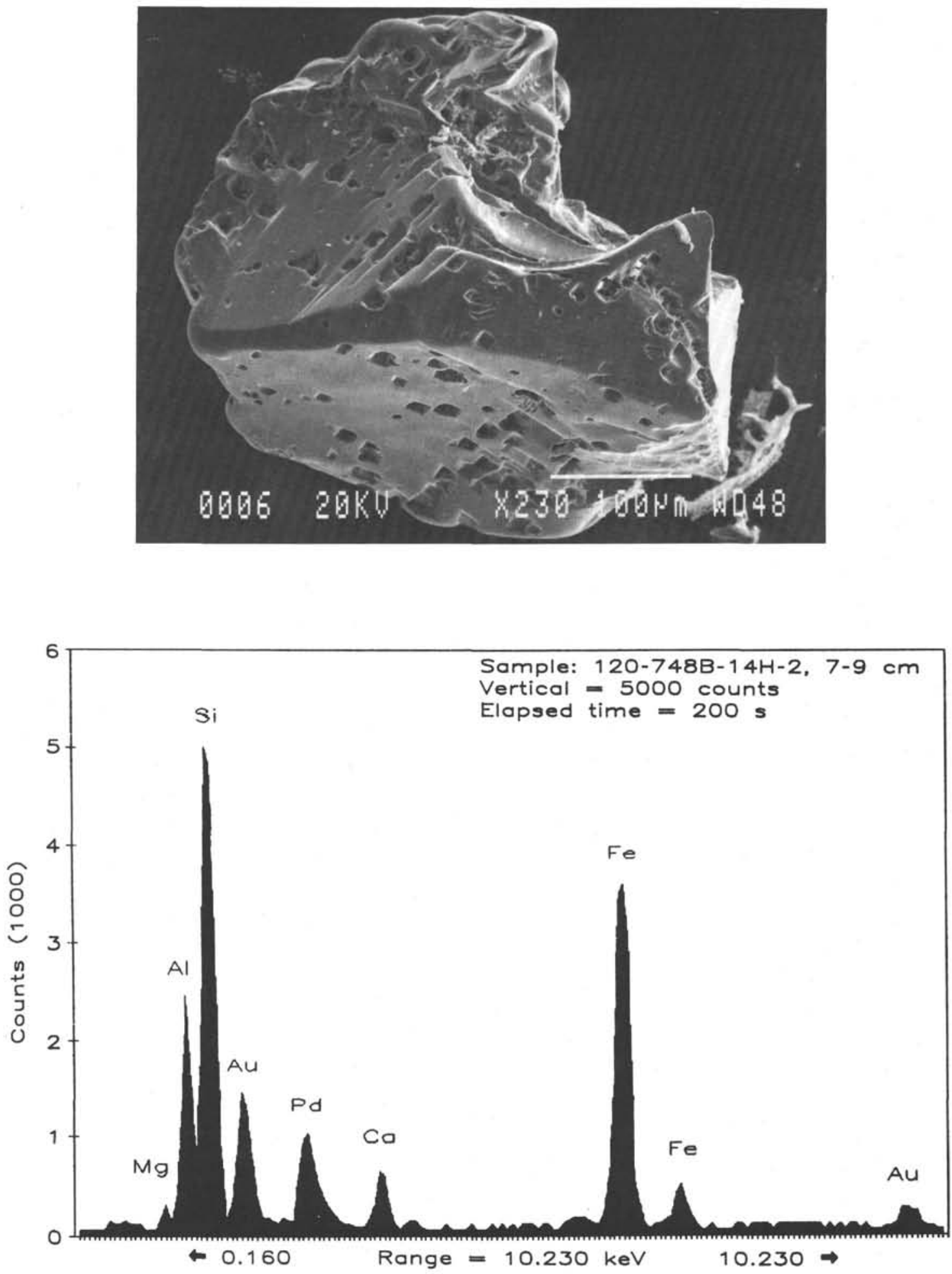

Figure 7. Scanning electron micrograph of etched (V-shaped markings), subangular garnet grain. If one ignores the emission peaks from the Au-Pd coating on the specimen, the elements displayed on the qualitative EDX spectrum are consistent with those given in the formula for this mineral $\left[\mathrm{X}_{3} \mathrm{Y}_{2}\left(\mathrm{SiO}_{4}\right)\right]$. Sample 120-748B-14H-2, 7-9 cm, $\times 230$. 

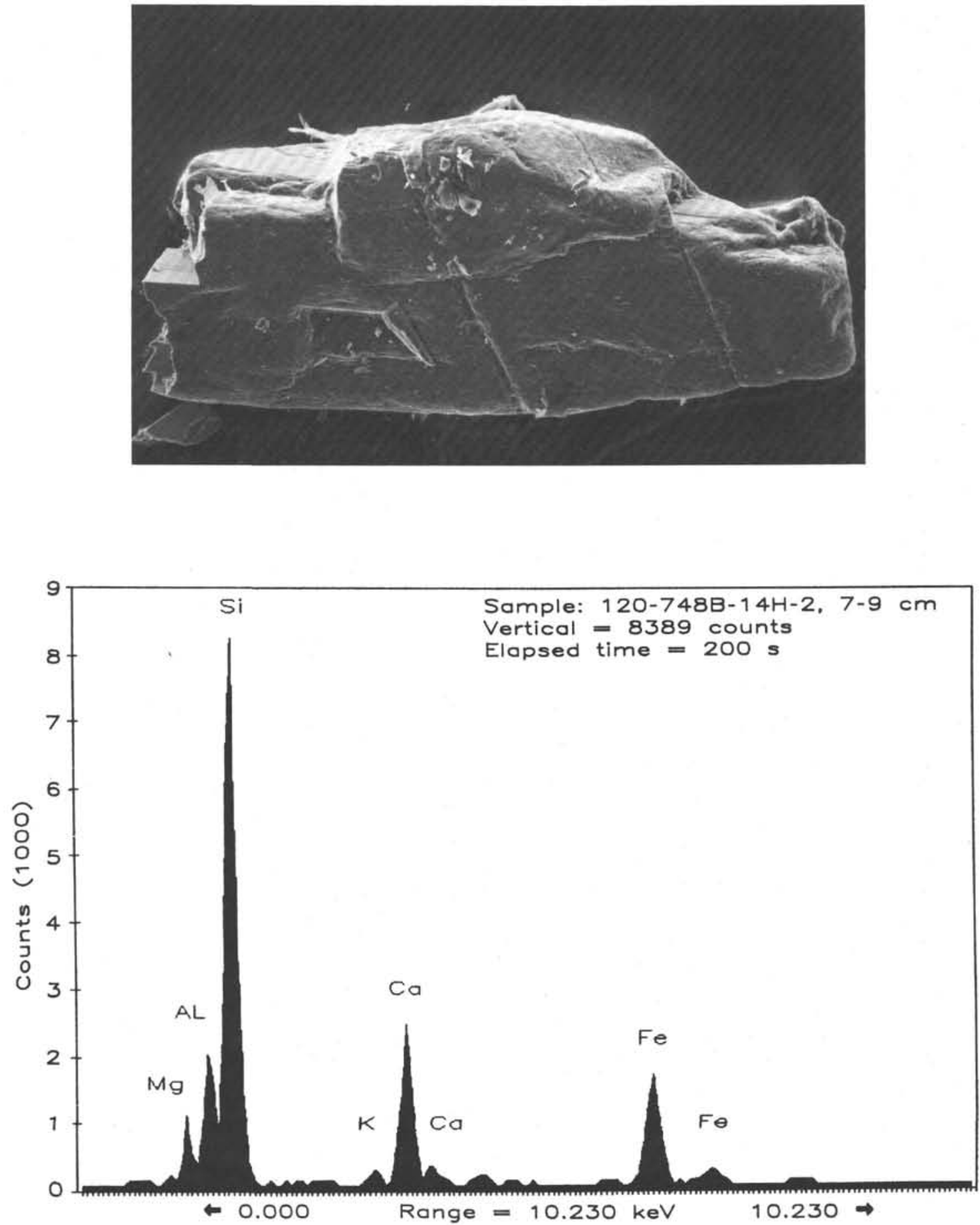

Figure 8. Scanning electron micrograph of subangular hornblende grain displaying $120^{\circ}-60^{\circ}$ cleavage pattern. The elements displayed on the qualitative EDX spectrum are in consistent with those in the formula for this mineral $\left[\left(\mathrm{NaCa}_{2}(\mathrm{Mg}, \mathrm{Fe}, \mathrm{Al},)_{5}(\mathrm{Si}, \mathrm{Al})_{8} \mathrm{O}_{22}(\mathrm{OH})_{2}\right]\right.$. Sample $120-748 \mathrm{~B}-14 \mathrm{H}-2,7-9 \mathrm{~cm}, \times 260$.

\section{Effects of Bioturbation}

Visual evidence of sediment bioturbation in Sections 120 748B-14H-1 and -2 shows that the siliceous nannofossil ooze, and presumably the IRD contained within, have been mixed a minimum of $18 \mathrm{~cm}$ bèlow the sharp contact at 115.85 mbsf (Figs. 3 and 4). Total accumulative effects of bioturbation have reworked the IRD over a vertical distance of $79 \mathrm{~cm}$. If we assume no bioturbation and a constant sedimentation rate of
$0.63 \mathrm{~cm} / \mathrm{k} . \mathrm{y}$., the data suggest that the duration of IRD accumulation was approximately $125,000 \mathrm{yr}$.

To reconstruct the duration of the clastic (IRD) deposition, bioturbation effects on the sediment must be factored out. Many studies have addressed the problem of bioturbation and its effects on interpreting the timing of paleoceanographic events by developing complex models to minimize or eliminate the effects of bioturbation (Guinasso and Schink, 1975; Peng et al., 1979; Huston, 1980; Officer, 1982). In this study, 
Table 2. Description of pebble-sized, ice-rafted debris found in Sample 120-748B-14H-2, 7-9 cm.

\begin{tabular}{lrll}
\hline Mineral & $\begin{array}{r}\text { Size } \\
(\mathrm{mm})\end{array}$ & \multicolumn{1}{c}{ Shape } & \multicolumn{1}{c}{ Color } \\
\hline Quartz & 3.5 & Subrounded & Clear \\
Quartz & 2.5 & Subrounded & Clear \\
Quartz & 2.0 & Subrounded & Light pale gray \\
Quartz & 2.5 & Subrounded & Light pale gray \\
Quartz & 3.0 & Subrounded & Light pale gray \\
\hline
\end{tabular}

we developed a simple model to minimize the effects of bioturbation based on the occurrence of the three largest clastic peaks. Mid-depth points were selected between the maximum and second largest clastic concentrations located below and above the maximum clastic peak. These mid-depth points were designated as the approximate first and last occurrences of the clastics. The adjusted vertical thickness of the interval of clastic material is $5 \mathrm{~cm}$. Assuming a constant sedimentation rate of $0.63 \mathrm{~cm} / \mathrm{k} . \mathrm{y}$. and a clastic interval of 5 $\mathrm{cm}$, the ice-rafting event may have occurred over a span of approximately $7900 \mathrm{yr}$.

\section{DISCUSSION}

\section{Source and Mode of Transport of the Lower Oligocene Clastics, Site 748}

As noted during the analyses described above, the depositional event that produced the lower Oligocene coarse clastic materials at Site 748 was of rather short duration, probably occurring over a span of less than $8000 \mathrm{yr}$. The biogenic component is poorly sorted, implying a lack of significant current winnowing. Possible sources and origins of the clastic materials include devitrified volcanic ash (from an ash fall or water-rafted pumice) and ice-rafted debris from local volcanic islands or distant sources to the south. The purpose of the various analyses performed on the clastic components was to discriminate among these various possibilities.

Quartz is a ubiquitous mineral found in a wide variety of sedimentary, metamorphic, and igneous rocks, including some volcanic ashes. Although we identify the angular shape, conchoidal fractures, and particular surface textures of the grains as glacial indicators, such features alone are not universally considered indicative of glacial environments, as some investigators feel that many of these features can be produced by other mechanisms (Brown, 1974). Thus, the quartz is not used alone to characterize the origin and source of the clastic materials.

More indicative of source is the composition of the heavy mineral assemblage. Of the minerals identified, garnet, which is common in the assemblage, is highly significant because it can generally be considered as characteristic of a metamorphic rock source. Although magnesium-rich garnet (spessartine) is known from volcanic rocks, such occurrences are rare and the grains so formed are usually euhedral, not anhedral, as in the majority of the garnet grains in our material. Furthermore, no garnets were noted in the basement basalts drilled by Leg 120 on the Kerguelen Plateau.

Among the other heavy minerals present, hornblende is known from both igneous and metamorphic rocks. Over the spectrum of volcanic rocks, however, hornblende is generally found in intermediate volcanics such as andesite, not tholeiites. Rutile is a widespread accessory mineral in igneous rocks, gneisses, and schists. Ilmenite occurs principally in close association with gabbros and diorities. Mica is found in igneous rocks and is abundant in schist and gneisses of lowand medium-grade metamorphic rocks. Tourmaline occurs in granite pegmatite and is also common as an accessory mineral in metamorphic rocks, especially schists and gneisses.

Overall, the heavy mineral suite observed in the clastic interval is characteristic of metamorphic and/or plutonic rock sources, not of volcanic ashes or lavas. By the same token, a local source can also be excluded. The Kerguelen edifice and the islands presently exposed on the plateau (Kerguelen, Heard, and Macdonald islands) are constructed of basalt tholeiites. Legs 119 and 120 drilled into basement basalt flows at four widely scattered locations on the plateau, and no continental basement was encountered (Barron, Larsen, et al., 1989; Schlich, Wise, et al., 1989).

The only feasible source for the heavy mineral fraction described is from the igneous and metamorphic basement complexes and overlying continental-derived sediments of the East Antarctic craton to the south, which is the nearest continental land mass to our study area. The only probable mechanism for transporting such material to the isolated and elevated Site 748 is by ice-rafting. As pointed out previously, the physiographic setting of the plateau would rule out the transport of such continental materials to this site by turbidity currents, and the material is too coarse to have been transported by nepheloid layers or wind.

Ice-rafting from Antarctica is quite reasonable in view of the recent documentations of early Oligocene glacial activity on the continent by drilling in such widely scattered localities as the Weddell Sea, Ross Sea, and Prydz Bay (see summary by Wise et al., this volume). A glacial origin and mode of transportation for the material is consistent with the angular nature and surface textures that characterize the quartz grains in the deposit (Fig. 4).

Because of the possibly that the isolated $1-\mathrm{cm}$ pebble recovered by James Zachos from Sample 120-748B-14H-1, 9-10 cm, might be Oligocene IRD, this core was reexamined at the ODP East Coast Repository by the J. R. Breza. We were suspicious that this pebble was a contaminant from the surface for a number of reasons. No other IRD or lithologic change had been noted in this portion of the core, which is logged as "drilling disturbed"' in Schlich, Wise, et al. (1989, p. 454). The ocean floor in this area is littered with Neogene erratics and IRD. Because no reentry cone was in place during the drilling of this portion of the hole, the action of the drill pipe and the water circulated from the hole would have created a cone of depression at the surface, promoting the caving of material downhole, where it can come to rest at the bottom of the hole between core runs. Reexamination of the core proved these suspicions to be correct in that the top of the core was not only disturbed but contained other sandsized clastic material as well that had been dragged several centimeters down the core liner. Such a situation is not uncommon among drill cores taken in the Southern Ocean (see further discussion by Wise et al., this volume).

\section{Significance of the Oligocene IRD at Site $\mathbf{7 4 8}$}

For a Paleogene IRD deposit beyond the margins of the Antarctic continent, the lower Oligocene occurrence at Site 748 is unique. It is an unambiguous occurrence of IRD with no outstanding question as to its nature or source. It occurs in abundance within a distinguishable stratum of siliceous nannofossil ooze, with grains coarse enough to be readily detected when making smear slides of the material and numerous enough to stand out when those slides are examined under the microscope. As such, this occurrence is the farthest north of any documented and undisputed example of Paleogene IRD yet discovered. 
Table 3. Lower Oligocene ice-rafted debris and glauconite apparent accumulation rates, Hole 748B.

\begin{tabular}{|c|c|c|c|c|c|c|c|}
\hline $\begin{array}{l}\text { Core, section, } \\
\text { interval }(\mathrm{cm})\end{array}$ & $\begin{array}{l}\text { Midpoint } \\
\text { depth } \\
\text { (mbsf) }\end{array}$ & $\begin{array}{c}\text { IRD } \\
\text { abundance } \\
\text { (grains/g) }\end{array}$ & $\begin{array}{c}\text { Glauconite } \\
\text { abundance } \\
\text { (grains/g) }\end{array}$ & $\begin{array}{l}\text { Approximate } \\
\text { dry-bulk } \\
\text { density } \\
\left(\mathrm{g} / \mathrm{cm}^{3}\right)\end{array}$ & $\begin{array}{l}\text { Approximate } \\
\text { sedimentation } \\
\text { rate }(\mathrm{cm} / \mathrm{k} . \mathrm{y} .)\end{array}$ & $\begin{array}{c}\text { IRD apparent } \\
\text { accumulation rate } \\
\text { (grains } / \mathrm{cm}^{2} / \mathrm{k} . \mathrm{y} \text {.) }\end{array}$ & $\begin{array}{c}\text { Glauconite } \\
\text { apparent } \\
\text { accumulation rate } \\
\text { (grains } / \mathrm{cm}^{2} / \mathrm{k} . y . \text {.) }\end{array}$ \\
\hline \multicolumn{8}{|l|}{$120-748-B$} \\
\hline $14 \mathrm{H}-1,65-69$ & 114.77 & 0 & 0 & 0.99 & 0.63 & 0 & 0 \\
\hline $14 \mathrm{H}-1,106-109$ & 115.18 & 1 & $<1$ & 0.99 & 0.63 & 1.6 & 0 \\
\hline $14 \mathrm{H}-1,118-119$ & 115.29 & 2 & 0 & 0.99 & 0.63 & 3.2 & 0 \\
\hline $14 \mathrm{H}-1,128-129$ & 115.39 & 2 & 0 & 0.99 & 0.63 & 3.2 & 0 \\
\hline $14 \mathrm{H}-1,135-139$ & 115.47 & 13 & 1 & 0.99 & 0.63 & 20.8 & 1.6 \\
\hline $14 \mathrm{H}-1,142-143$ & 115.53 & 15 & 5 & 0.99 & 0.63 & 24.1 & 8.0 \\
\hline $14 \mathrm{H}-1,145-149$ & 115.57 & 17 & 5 & 0.99 & 0.63 & 27.3 & 8.0 \\
\hline $14 \mathrm{H}-2,4-5$ & 115.65 & 110 & 18 & 0.99 & 0.63 & 176.3 & 28.9 \\
\hline $14 \mathrm{H}-2,7-9$ & 115.68 & 228 & 27 & 0.99 & 0.63 & 365.6 & 43.3 \\
\hline $14 \mathrm{H}-2,14-15$ & 115.75 & 54 & 11 & 0.99 & 0.63 & 86.6 & 17.6 \\
\hline $14 \mathrm{H}-2,20-21$ & 115.81 & 30 & 28 & 0.99 & 0.63 & 48.1 & 44.9 \\
\hline $14 \mathrm{H}-2,24-26$ & 115.85 & 2 & 25 & 0.99 & 0.63 & 3.2 & 40.1 \\
\hline $14 \mathrm{H}-2,30-31$ & 115.91 & 3 & 12 & 0.99 & 0.63 & 4.8 & 19.2 \\
\hline $14 \mathrm{H}-2,35-39$ & 115.97 & $<1$ & 4 & 0.99 & 0.63 & 0 & 6.4 \\
\hline $14 \mathrm{H}-2,54-56$ & 116.15 & 0 & 1 & 0.99 & 0.63 & 0 & 1.6 \\
\hline $14 \mathrm{H}-2,100-104$ & 116.62 & 0 & 0 & 0.99 & 0.63 & 0 & 0 \\
\hline
\end{tabular}

Notes: The size of the ice-rafted debris and glauconite analyzed ranges between $\geq 250 \mu \mathrm{m}$ and $<2 \mathrm{~mm}$.

Most valuable is the presence of the IRD in a biosiliceous and carbonate ooze sequence for which a paleomagnetic stratigraphy has been established. This allows precise dating of the ice-rafting event by siliceous and calcareous microfossils as well as magneto- and chemostratigraphy. According to the age model of Wei et al. (this volume), this IRD occurs just below Chron $13 \mathrm{~N}$ in an interval dated between 35.8 and 36.0 Ma. In addition, a clear correlation can be established between this occurrence and the well-known earliest Oligocene $\delta^{18} \mathrm{O}$ excursion within the stable isotope record (Zachos, this volume, Chapter 44 , and references therein). This is a remarkable correlation, with a nearly one-for-one correspondence among samples between IRD abundance and the intensity of the positive $\delta^{18} \mathrm{O}$ excursion. Such a correspondence is not noted, for instance, in the records for the Eocene Eltanin cores (Wei, this volume, Chapter 63). The fact that the isotope excursion, IRD occurrence, and lithology change to a siliceous nannofossil ooze coincide at the same point in the core provides three independent lines of evidence to help document the ice-rafting event and to vouch for its authenticity. In addition, a detailed analysis of the nannofossils within the sequence has provided confirmation of sharp cooling of the overlying water mass (Wei et al., this volume, Chapter 55). We would expect that a detailed faunal analysis would provide similar evidence, as it did for this event at Site 511 on the Falkland Plateau (Wise et al., 1985, fig. 6).

An important footnote to the IRD occurrence is the inclusion within this interval of fish tooth and/or bone fragments. Except for this meager evidence, Quilty (this volume, Chapter 24) observes that no other fossil record exists of the predecessors of the notothenioid-dominated fish fauna of the modern Antarctic ecosystem (see also Eastman and Grande, 1989). Quilty's search through the Leg 120 cores for additional evidence was frustrated by the fact that nototheniid otoliths are aragonite in composition and highly susceptible to dissolution.

\section{Implications for Ice Sheet and Paleoceanographic Development}

Based on the peak distribution of the $>250-\mu \mathrm{m}$ size fraction (Fig. 3), it appears that the IRD defines a single ice-rafting event with a duration of less than $8000 \mathrm{yr}$. This is not to imply that the material was deposited by a single iceberg, but rather by a series of icebergs emanating from the margin of the
Antarctic continent. Such icebergs must have been of considerable size to have reached this site located nearly $1000 \mathrm{~km}$ north of the present Antarctic coastline (Fig. 1). Presumably, surface waters during the early Oligocene would have been warmer than those in this area today (see discussion below). The record at Site 748 would suggest a relatively severe and precipitous glacial event on Antarctica, as compared with any previous episode, but one of short duration.

The nearest large source of early Oligocene icebergs would appear to have been Prydz Bay, where Leg 119 drilling proved the existence of extensive lower Oligocene glaciomarine sediments with glacial ice thought to have been grounded well out onto the continental shelf (Leg 119 Shipboard Scientific Party, 1988). Prydz Bay drains $20 \%$ of the present-day Antarctic Ice Sheet. Because of the influence of the Polar easterlies and the westward flowing coastal current, however, Prydz Bay is not the source of icebergs reaching the Kerguelen Plateau today. For Prydz Bay to have been the source of icebergs reaching Site 748 during the earliest Oligocene, circulation patterns must have been considerably different then, allowing the bergs to drift northward over the plateau (Wise et al., this volume). Otherwise, the iceberg source would have been farther east along the Antarctic continental margin, thus necessitating even longer paths for bergs to reach the site and even larger icebergs to make such a traverse.

Numerous other sources of early Oligocene icebergs apparently existed. The records at the CIROS-1 site showed that glacial ice was intermittently grounded at sea level in the Ross Sea during this time (Barrett et al., 1989), and there is ample evidence of ice-rafting out to the continental margin at Site 693 in the southern Weddell Sea, even during the later portion of the early Oligocene (Barker, Kennett, et al., 1988; Grobe et al., 1990). One can speculate that if a more complete lower Oligocene (33-36 Ma) record had been present at Site 693, it would have contained an even more extensive IRD record, comparable with those found within that interval at Prydz Bay and in the Ross Sea. It appears, however, that intense glacial activity was responsible for the disconformity at that site, and that a concomitant increase in the strength of oceanic currents may have produced early Oligocene hiatuses at many deepsea sites, such as at Site 690 , which is offshore from Site 693 at Maud Rise (Barker, Kennett, et al., 1988).

The extent of early Oligocene Antarctic glacial activity demonstrated to date and the size of the icebergs needed to 
survive the passage to localities as far north as Site 748 would imply the existence of some sort of an ice sheet, a question of considerable speculation and debate before the Leg 119 and 120 drilling campaigns. Many lines of evidence, both direct and indirect, have been brought to bear on this question, none of which are universally accepted as conclusive. Although considerable new evidence was discovered during recent ODP cruises to the Southern Ocean, no sites on the Antarctic margin recovered a continuous record through the Cenozoic glacial/preglacial interface, and it has not been possible to date with any certainty the oldest glaciomarine sequences in Prydz Bay (Leg 119 Scientific Party, 1988). Without a more coherent record of the initiation of Cenozoic glaciation on Antarctica, much of the available evidence and its evaluation remains open to interpretation. The following discussion is no exception to this generalization. It is intended to bring out a few points we consider most salient for making our interpretation rather than to attempt a complete review of the many opinions given in the literature on this subject.

Mercer $(1973,1978)$ suggested that icebergs produced by mountain glaciers grounded at sea level are too small to travel considerable distances from their source, and that only ice sheets produce bergs large enough to traverse several degrees of latitude (see the discussion of this point by Wei, this volume, Chapter 55). During major glacial episodes, however, there should be a concomitant cooling of surface waters, which would tend to prolong such traverses.

Cooling of surface waters of the high-latitude Southern Ocean is implied in the available nannofossil and stable isotope records from Site 748 and elsewhere in the Southern Ocean (Wei et al., this volume, Chapter 55; Zachos et al., this volume, Chapter 44, and references therein). As pointed out by Poore and Matthews (1984) among others, however, the interpretation of surface-water isotopic temperatures in the high southern latitudes is complicated by the possibility of reduced salinities caused by excessive precipitation (which would produce more negative isotopic values) and by the possible effects of ice volume (which would yield more positive values).

Early Oligocene surface-water paleotemperature estimates based on stable isotope studies for these latitudes vary widely, depending on whether or not one applies corrections for ice volume and/or reduced salinities (see discussions by Poore and Matthews, 1984; Wei and Wise, in press; Wise et al., this volume, Chapter 56). Shackleton and Kennett (1975) applied no such corrections and derived surface paleotemperatures of about $5^{\circ}$ to $7^{\circ} \mathrm{C}$ for Site 277 , then situated at about $50^{\circ} \mathrm{S}$ latitude. This is a value similar to that of today for this latitude. This implied to Shackleton and Kennett (1975) that surface paleotemperatures at the Antarctic coast were near freezing, which they believed would support the formation of sea ice. In their opinion, the continent would have been heavily glaciated, but not by continental glaciers. Valley glaciers, however, would have extended down to sea level (Shackleton and Kennett, 1975). On the other hand, Oerlemans (1982) suggests from modeling experiments that coastal atmospheric temperatures around freezing could support a substantial Antarctic ice sheet, with ice thicknesses as great as $4 \mathrm{~km}$.

Additional opinions as to presence or absence of an ice sheet during early Oligocene times have been made from seafloor isotopic temperature estimates derived from benthic foraminifers. Among these, Miller and Fairbanks (1983), Keigwin and Keller (1984), Miller and Thomas (1985), Wise et al. (1985), Keigwin and Corliss (1986), and Miller et al. (1987) all suggested from their various analyses that there must be an ice-volume effect expressed in the lower Oligocene isotopic curves. At Site 511 on the Falkland Plateau (present water depth of $2737 \mathrm{~m}$; latitude, $50^{\circ} \mathrm{S}$ ), Wise et al. (1985) noted that if an ice-volume effect were not taken into consideration, then the isotopic paleotemperatures for the early Oligocene calculated on the basis of an "ice-free world" would equal those of the present day, thus implying a present-day temperature/ circulation regime for that region. Bottom temperatures at that depth would have fluctuated between about $0^{\circ}$ and $4^{\circ} \mathrm{C}$ (Wise et al., 1985, fig. 6). Such an oceanographic regime should produce a deep-sea sedimentary record with abundant IRD, dropstones, carbonate-free sediments at comparable depths, and very low diversities of calcareous planktonic microfossils, which was clearly not the case for the Oligocene of the eastern Falkland Plateau, according to DSDP Leg 36 and 71 drill records.

Wise et al. (1985), therefore, envisioned for the early Oligocene an intermediate stage between the present conditions and an "ice-free world," and postulated the presence of a moderate-sized ice sheet on East Antarctica. Drawing an analogy with the North American Pleistocene Ice Sheet, they suggested that an Oligocene ice sheet on Antarctica would be centered on the relatively low elevations of the plateaus of the craton (rather than in mountain ranges) and nourished with moisture from interior seaways such as those postulated by Zinsmeister (1978) and Webb et al. (1984). Like the North American Ice Sheet, such a feature could have rapidly advanced and retreated great distances across the continent over short periods of time. Wise et al. (1985, p. 303) concluded that:

If the ice sheet did reach sea level during the early Oligocene, it may well have done so along the interior seaways where any ice-rafting would have been rather localized. This is not to suggest that mountain glaciers did not form as well. They would also have been more localized and volumetrically less important, however, compared to the cratonic ice sheet.

Results from recent drilling in the Ross Sea (Barrett et al., 1987, 1989) and Prydz Bay (Barron, Larsen, et al., 1989) have shown that, as Shackleton and Kennett (1975) predicted, early Oligocene ice did indeed reach sea level. Leg 113 drilling in the Weddell Sea (Barker, Kennett, et al., 1988) further showed that significant ice-rafting occurred out to at least the continental slope, and the Leg 120 results reported here demonstrate that during at least one major cooling event, very large icebergs carried sediments over $1000 \mathrm{~km}$ beyond the margins of the continent.

Considering all of the available evidence, particularly the benthic foraminifer isotopic evidence from deep-water Site 511 on the Falkland Plateau, we believe that an early Oligocene ice sheet as postulated by Wise et al. (1985) and others did exist. It may have existed only for short periods of time, but it was evidently not always as well "hidden" on the interior of the continent as Wise et al. (1985) originally envisioned because of their inability to detect any evidence of ice-rafting at their Falkland Plateau site.

The short duration of the early Oligocene IRD event as recorded at Site 748 would make it difficult to detect at other Southern Ocean sites. For this reason, it may have been missed elsewhere. In addition, the lower Oligocene interval is frequently characterized by hiatuses, presumably as a result of related ocean circulation changes and reorganization; therefore, such a record is not likely to be preserved at many sites. The short duration of the event would also mean that it may not be as easily detected as a distinct and separate eustatic sea-level event in lower latitude regions. Miller et al. (1985) noted that the major Cenozoic sea-level 
event occurred during the middle rather than the earliest Oligocene, and they constructed a combined subsidence/ eustatic sea-level model in an attempt to account for the more subtle expression of the early Oligocene event in the Vail sea-level curve.

Based on the extensive Oligocene record from the CIROS-1 site, Barrett et al. (1989) concluded that the early Oligocene ice sheet was "temperate" in nature. They did not find evidence to imply the existence of ice shelves or even of significant sea ice, yet they believed that the presence of grounded ice in the Ross Sea was probably supported by an ice sheet on East Antarctica. Part of the evidence on which they based their conclusion was the presence of plants on Antarctica throughout the Oligocene, as first pointed out by Kemp (1972) on the basis of reworked palynomorphs in marine strata around the continent. This was confirmed at the CIROS-1 site by relatively abundant in situ palynomorphs (Mildenhall, 1989) in addition to the presence of a Nothofagus leaf in an interglacial mudstone between two upper Oligocene tills in the CIROS-1 cores (Hill, 1989). Glacial conditions on the continent were thought to be sufficiently mild to allow such vegetation to persist in coastal refugia, from which they could recolonize southern beach forests in the Ross Sea area during interglacials.

This style of glaciation would be consistent with the limited occurrence of lower Oligocene IRD over the Kerguelen Plateau, as well as with the stable isotopic record which, in our opinion, reflects some ice-volume effect during a brief glacial maximum. On the other hand, one can argue that IRD deposited at Site 748 came solely from alpine glaciers that reached sea level. Icebergs calved from such glaciers might carry more sediment than the larger bergs derived today from continental ice or ice shelves. Modern shelf ice is fairly clean as it is composed partly of ice frozen from seawater. Based on the results of the CIROS-1 drilling, the glacial ice in that region was wet based and ice shelves did not exist in the Ross Sea area (Barrett et al., 1989). Any ice shelves that may have formed around East Antarctica would likely have been quite small and ephemeral. Any glacial ice, however, either from valley or continental glaciers, moving over previously unglaciated, and therefore easily erodible terrain, would likely pick up considerable debris (Warnke, 1970). It would be impossible, solely from the evidence at Site 748 , to determine whether the IRD was derived from Alpine or continental glaciers. The presence of this IRD so far removed from the Antarctic continent, however, argues for the existence of very large icebergs, possibly broken from small ice shelves. Its presence certainly strengthens the growing number of arguments for the existence of significant earliest Oligocene ice buildups on the Antarctic continent.

The fact that no such IRD was detected in upper Oligocene through middle Miocene sediments on the Kerguelen Plateau is something of a conundrum. Ice buildup on Antarctica could have been less extensive or ice-rafting less intense during this period, which is suggested as well by the upper Oligocene record at Site 693 in the Weddell Sea where little or no IRD is present (Grobe et al., 1990). This contradicts, however, evidence from the Ross Sea and elsewhere that suggests that the late Oligocene glaciations were actually more intense than the earliest Oligocene event (see Barrett et al., 1989). Alternatively, late Oligocene circulation patterns may have been sufficiently different to prevent such materials from accumulating at sites distant from the continent.

\section{Paleoceanographic History}

The association of IRD, glauconite, ichthyoliths, and the positive $\delta^{18} \mathrm{O}$ excursion within the unusually diatom-rich lower Oligocene nannofossil ooze stratum at Site 748 has important implications for the oceanographic development of the water masses overlying the site as well as for the evolution of global climate. This association is not believed to be fortuitous.

Diatoms, sufficiently numerous to be recorded on the smear slide logs for Site 748, first appear in the late Eocene (Fig. 3). Indeed, Zachos et al. (this volume, Chapter 44) recorded a positive isotopic "precursor" event at this point, which heralds a late Eocene cooling and apparently the enhancement of upwelling sufficient to stimulate diatom production. This may signal the first development of a cold-water mass over the site.

Diatom productivity reached a peak during the IRD event and then diatoms persisted at this site through the remainder of the Oligocene (Fig. 3), an indication that the cold-water mass, once developed, remained over the site during the rest of the Paleogene. Radiolarian evidence suggests that a similar water mass was positioned over the Falkland Plateau (latitude $51^{\circ} \mathrm{S}$ ) at the time of the major isotopic excursion during the earliest Oligocene (Wise et al., 1985, fig. 6).

The occurrence of large ichthyolith fragments within the IRD interval further suggests upwelling and the inception of a highly productive trophic structure within the cold surfacewater mass. The fact that no such material has been noted outside of the IRD layer probably attests to the vigor of the upwelling and to the richness of the nutrient levels in the upwelled waters. Fischer and Arthur (1977) noted that during times of sluggish oceanic circulation, bottom waters become rich sinks for dissolved nutrients. Upon overturn, such bottom waters should provide especially high levels of nutrients to the surface waters. Kennett and Shackleton (1976) correlated the development of psychrospheric circulation, at least on a permanent basis, with the earliest Oligocene stable isotope excursion. If so, then the newly upwelled bottom waters were probably exceedingly nutrient-rich and a food chain could quickly develop that would support large numbers of higher level organisms. Kennett (1978) noted that very important developments in the evolution of marine vertebrate faunas took place during the Oligocene. The development of filter feeding originated in Southern Ocean cetaceans and was induced by increased biogenic productivity in the Southern Ocean (Fordyce, 1977, 1989). The earliest known, positively identified baleen whales (Mysticeti) are of earliest Oligocene in age, as are the first Odontocetes (tooth whales, dolphins, and porpoises). The major evolutionary radiations of these groups, with their new feeding strategies, probably took place during the early Oligocene and developed further during the early Miocene, following the opening of Drake Passage and the development of a true, deep-water, circum-Antarctic current (Fordyce, 1989).

Productivity in the Southern Ocean region during the Oligocene, therefore, although on the rise, would have been lower than afterward. This serves to highlight the significance of the singular occurrence of ichthyoliths in the lowermost Oligocene at Site 748 and suggests that forms that took advantage of the initial enhanced productivity were opportunistic species of extant vertebrate faunas, which probably increased in number but not necessarily in diversity, given the short duration of the event. The stage was being set, however, for further developments in vertebrate evolution as the circulation patterns of the Southern Ocean began to change.

Although glauconite forms in greatest quantities in shelfdepth waters, it can also form at much greater depths, as noted previously. Its formation is enhanced by higher organic contents in the sediments and diminished sedimentation rates or the development of hiatuses. Its presence in the IRD layer 
may have resulted from higher enrichment of organic matter resulting from increased productivity in the water column and/or from a drop in sedimentation rate not detectable within the limits of our bio- and magnetostratigraphic resolution at this site. The latter is a distinct possibility because the glauconite peaks at the contact between the nannofossil ooze and the overlying siliceous nannofossil ooze (at $115.85 \mathrm{~m}$ in Fig. 3). As this contact is quite sharp, it could represent a minor disconformity not detectable at our scale of resolution.

Alternatively, the glauconite could have been introduced along with the IRD by means of ice-rafting. Leg 119 results do show that ice was grounded well out onto the continental shelf at this time. Grobe et al. (1990) noted a remarkable amount of well-sorted glauconite (up to $25 \%$ of the sediment) along with IRD in the lower Oligocene (lithologic Unit V) at Site 693. They correlate this with increasing glacial conditions. The introduction of glauconite by ice-rafting at Site 748 seems unlikely, however, because the glauconite and IRD peaks do not coincide at Site 748 ; the glauconite peak occurs lower in the sequence (Fig. 3).

A third possibility is that the glauconite was eroded from submarine outcrops of Cretaceous sediments in this area. Glauconite was quite common in the 400 -m-thick Upper Cretaceous section at Site 748. If reorganization in deep circulation patterns was occurring during the earliest Oligocene, glauconite may have been eroded from outcrops that could have been exposed along the large fault scarps near this site (see Schlich, Wise, et al., 1989, "Site 748"' chapter). As no evidence of reworked Cretaceous microfossils have been detected in the Oligocene samples, however, this possibility is also considered unlikely.

\section{SUMMARY}

Sand- and pebble-sized lower Oligocene clastic detritus recovered at Site 748 on the Central Kerguelen Plateau are interpreted to be IRD for the following reasons:

1. The isolated location of this site high on the plateau and remote from continental land sources excludes transport of coarse clastic materials to the site by turbidity currents, nepheloid layers, or wind.

2. A volcanic ash source is excluded because no volcanic glass was observed in this part of the section, and the heavy mineral assemblage contains common anhedral garnet grains, which would most likely denote a metamorphic source rock. The remaining heavy mineral assemblage supports a metamorphic or plutonic rather than a volcanic ash or lava rock source.

3. The predominance of quartz and the composition of the heavy mineral assemblage also rule out a local source from the Kerguelen Plateau, which is a basaltic volcanic edifice.

4. The quartz grains are angular and exhibit conchoidal fractures and surface textures characteristic of grains found in glacial environments.

5. There is a close correspondence between the peak in IRD abundance, a lithology change to siliceous nannofossil ooze, a major positive $\delta^{18} \mathrm{O}$ shift in the stable isotope record (Zachos et al., this volume, Chapter 44), and a sharp increase in the percentage of cold-water nannoplankton in the surface waters (Wei et al., this volume, Chapter 55).

The IRD is thought to have been deposited during a single, short-lived but severe glacial episode, perhaps lasting no more than $7900 \mathrm{yr}$. The wider distribution of the clastic materials within the interval is attributed to bioturbation.

The source of the IRD was probably the igneous and metamorphic basement complexes and overlying sediments of East Antarctica. If so, this is the lowest latitudinal occurrence known for lower Oligocene IRD in a pelagic environment. This direct physical evidence of ice-rafting over $1000 \mathrm{~km}$ from the present-day Antarctic margin requires conveyance by large icebergs and further argues for the existence of a continental ice sheet on Antarctic during the earliest Oligocene, however ephemeral and short lived its existence may have been. No such IRD was observed in upper Oligocene or lower Miocene sediments at this site.

Associated with the IRD are biosiliceous-rich nannofossil ooze, fish skeletal debris (ichthyoliths), and glauconite. The co-occurrence of these various elements is probably not fortuitous, but it does denote changes in patterns and/or intensities of oceanic circulation associated with the profound climatic cooling that accompanied the IRD event. The attendant climatic event apparently enhanced upwelling and surface-water productivity and the development of a trophic structure that supported abundant vertebrate marine life, perhaps an important step in the evolution of vertebrate marine faunas. We are aware of no other fish fauna remains from Southern Ocean sediments.

\section{ACKNOWLEDGMENTS}

We wish to dedicate this paper to Joanne Hayes, whose long, faithful, and able laboratory assistance on this and a companion paper (Breza, this volume, Chapter 14) was curtailed at the penultimate stage by a serious automobile accident; we wish her a full recovery. Figures 2, 3, 5 and 7 were published in Wise et al. (1991), and we thank Academic Press for permission to reproduce them here. We are also indebted to Dennis Cassidy and Ami Kaharoeddin, Curators of the Antarctic Research Facility (FSU), for use of their laboratory facilities, much help with library sources, and their steadfast support and encouragement of our Antarctic research over many years. David Harwood kindly provided preprints of his numerous papers, and our shipboard colleagues provided helpful discussion as well as a stimulating and lively atmosphere aboard ship. Steven Kish supplied useful information on characteristics and sources of heavy minerals. Wuchang Wei and James Pospichal kindly assisted with the preparation of the manuscript in many ways; and Brian Bornhold, Ellen Thomas, Wuchang Wei, and an unnamed referee provided helpful critical reviews of the manuscript. Kim Riddle and Sandee Silverman operated the $\mathrm{SEM} /$ probe; the micrographs and probe data were displayed previously in poster sessions by Breza et al. (1988, 1989). Woodward-Clyde Consultants (Tallahassee, FL) assisted with drafting and clerical support. We thank both our wives, Pam Breza and Cindy Wise, and families for putting up with our long months away and late nights. Laboratory support was provided by USSAC funds and NSF Grant No. DPP 89-17976.

\section{REFERENCES}

Anderson, D. M., 1985. Pliocene paleoceanography of the Southern Ocean and the development of the West Antarctic ice sheet [M.S. thesis]. San Jose State Univ., San Jose, CA.

Barker, P. F., Kennett, J. P., et al., 1988. Proc. ODP, Init. Repts., 113: College Station, TX (Ocean Drilling Program).

Barrett, P. J. (Ed.), 1986. Antarctic Cenozoic history from the MSSTS-1 drillhole, McMurdo Sound. DSIR Bull. N. Z., 237.

Barrett, P. J., Hall, K. J., Hambrey, M. J., Pyne, A. R., and Robinson, P. H., 1987. Cenozoic glacial and tectonic history from CIROS-1, McMurdo Sound. 5th Int. Symp. Antarct. Earth Sci., Cambridge, U.K. (Abstract)

in press. Cenozoic glacial and tectonic history from CIROS-1, McMurdo Sound. In Thomson, M.R.A., Cram, J. A., and Thomson, J. W. (Eds.), Geological Evolution of Antarctica: Cambridge (Cambridge Univ.). 
Barrett, P. J., Hambrey, M. J., Harwood, D. M., Pyne, A. R., and Webb, P.-N., 1989. Synthesis. In Barrett, P. J. (Ed.), Antarctic Cenozoic History from the CIROS-1 Drillhole, McMurdo Sound, DSIR Bull. N. Z., 245:241-251.

Barron, J., Larsen, B., et al., 1989. Proc. ODP, Init. Repts., 119: College Station, TX (Ocean Drilling Program).

Barron, J. A., Baldauf, J. G., Barrera, E., Caulet, J.-P., Huber, B. T. Keating, B. H., Lazarus, D., Sakai, H., Thierstein, H. R., and Wei, W., 1991. Biochronologic and magnetochronologic synthesis of Leg 119 sediments from the Kerguelen Plateau and Prydz Bay, Antarctica. In Barron, J., Larsen, B., et al., Proc. ODP, Sci. Results, 119: College Station, TX (Ocean Drilling Program), 813-848.

Birkenmajer, K., Delitata, M. C., Narebski, W., Nicoletti, M., and Petrucciani, C., 1986. Geochronology of Tertiary island-arc volcanics and glacigenic deposits, King George Island, South Shetland Islands (West Antarctica). Bull. Pol. Acad. Sci. Earth Sci., 34:257-273.

Birkenmajer, K., Dudziak, J., and Tokarski, A. K., 1988. Palaeogene calcareous nannoplankton from a neptunian dyke in the Low Head Member: its bearing on the age of the Polonez Glaciation in West Antarctica. Stud. Geol. Pol., 95:7-25.

Birkenmajer, K., and Gazdzicki, A., 1986. Oligocene age of the Pectin Conglomerate on King George Island, West Antarctica. Bull. Pol. Acad. Sci. Earth Sci., 34:219-226.

Bornhold, B. D., 1983. Ice-rafted debris in sediments from Leg 71, southwest Atlantic Ocean. In Ludwig, W. J., Krasheninnikov, V. A., et al., Init. Repts. DSDP, 71: Washington (U.S. Govt. Printing Office), 307-316.

Breza, J. R., Wise, S. W., Jr., and Leg 120 Shipboard Scientific Party, 1988. Lower Oligocene ice-rafted debris on the Central Kerguelen Plateau, ODP Leg 120: evidence for East Antarctica continental glaciation. Geol. Soc. Am. Abstr. Programs, 69. (Abstract)

Breza, J. R., Wise, S. W., Jr., Zachos, J. C., and the ODP Leg 120 Shipboard Party, 1989. Lower Oligocene ice-rafted debris at $58^{\circ} \mathrm{S}$ on the Kerguelen Plateau: the "smoking gun" for the existence of an early Oligocene ice sheet on East Antarctica. Third Int. Conf. Paleo-oceanography, Cambridge, U.K. (Abstract)

Brown, J. E., 1974. Depositional histories of sand grains from surface textures. Nature, 242:396-398.

Eastman, J. T., and Grande, L., 1989. Evolution of the Antarctic fish fauna with emphasis on the Recent notothenioids. In Crame, J. A. (Ed.), Origins and Evolution of the Antarctic Biota. Geol. Soc. Spec. Publ. London, 47:241-252.

Fischer, A. G., and Arthur, M. A., 1977. Secular variations in the pelagic realm. In Cook, H. E., and Enos, P. (Eds.), Deep Water Carbonate Environments. Spec. Publ. Soc. Econ. Paleontol. Mineral., 25:19-50.

Fordyce, R. E., 1977. The development of the circum-Antarctic current and the evolution of the Mysticeti (Mammalia: Cetacea). Palaeogeogr., Palaeoclimatol., Palaeoecol., 21:265-271.

1989. Origins and evolution of Antarctic marine mammals. In Crame, J. A. (Ed.), Origins and Evolution of the Antarctic Biota. Geol. Soc. Spec. Publ. London., 47:269-281.

Gazdzicka, E., and Gazdzicki, A., 1985. Oligocene coccoliths of the Pecten Conglomerate, West Antarctica. Neues Jahrb. Geol. Palaeontol. Monatsh., 12:727-735.

Gazdzicki, A., 1989. Planktonic foraminifera from the Oligocene Polonez Cove Formation of King George Island, West Antarctica. Pol. Polar Res., 10:47-55.

Grobe, H., Fütterer, D. K., and SpieB, 1990. Oligocene to Quaternary sedimentation processes on the Antarctic continental margin, ODP Leg 113, Site 693. In Barker, P. F., Kennett, J. P., et al., Proc. ODP, Sci. Results, 113: College Station, TX (Ocean Drilling Program), 121-131.

Guinasso, N. L., Jr., and Schink, D. R., 1975. Quantitative estimates of biological mixing rates in abyssal sediments. J. Geophys. Res., 80:3032-3043.

Haq, B. U., Hardenbol, J., and Vail, P. R., 1987. Chronology of fluctuating sea levels since the Triassic. Science, 235:1156-1167.

Harwood, D. M., Barrett, P. J., Edwards, A. R., Rieck, H. J., and Webb, P.-N., 1989. Biostratigraphy and chronology. In Barrett, P. J. (Ed.), Antarctic Cenozoic History from the CIROS-1 Drillhole, McMurdo Sound. DSIR Bull. N. Z., 245:231-239.
Harwood, D. M., Webb, P. N., and Barrett, P. J., in press. Cenozoic glacial history of Antarctica: evidence for multiple glacial/deglacial cycles and marine sedimentation in Antarctic interior basins. Paleoceanography.

Hayes, D. E., Frakes, L. A., et al., 1975. Init. Repts. DSDP, 28 : Washington (U.S. Govt. Printing Office).

Hill, R. S., 1989. Fossil leaf. In Barrett, P. J. (Ed.), Antarctic Cenozoic History from the CIROS-1 Drillhole, McMurdo Sound: DSIR Bull. N. Z., 245:143-144.

Huston, W. H., 1980. Bioturbation of deep-sea sediments: oxygen isotopes and stratigraphy uncertainty. Geology, 8:127-130.

Keany, J., Ledbetter, M. T., Watkins, N. D., and Huang, T. C., 1976. Diachronous deposition of ice-rafted debris in sub-antarctic deepsea sediments. Geol. Soc. Am. Bull., 87:873-882.

Keigwin, H. D., and Corliss, B. H., 1986. Stable isotopes in late middle Eocene to Oligocene foraminifera. Geol. Soc. Am. Bull., 97:335-345.

Keigwin, H. D., and Keller, G., 1984. Middle Oligocene cooling from equatorial Pacific DSDP Site 77B. Geology, 12:16-19.

Kemp, E. M., 1972. Reworked palynomorphs from the west ice shelf area, East Antarctica, and their possible geological and palaeoclimatological significance. Mar. Geol., 13:145-157.

Kennett, J. P., 1978. The development of planktonic biogeography in the Southern Ocean during the Cenozoic. Mar. Micropaleontol., 3:301-345.

Kennett, J. P., and Barker, P. F., 1990. Latest Cretaceous to Cenozoic climate and oceanographic developments in the Weddell Sea, Antarctica: an ocean-drilling perspective. In Barker, P. F., Kennett, J. P., et al., Proc. ODP, Sci. Results, 113: College Station, TX (Ocean Drilling Program), 937-960.

Kennett, J. P., and Brunner, C. A., 1973. Antarctic late Cenozoic glaciation: evidence for initiation of ice-rafting and inferred bottom water activity. Geol. Soc. Am. Bull., 84:2043-2052.

Kennett, J. P., and Shackleton, N. J., 1976. Oxygen isotopic evidence for the development of the psychrosphere 38 m.y. ago. Nature, 260:513-515.

Kennett, J. P., and Stott, L. D., 1990. Proteus and proto-oceanus: ancestral paleogene oceans as revealed from Antarctic stable isotopic results: ODP Leg 113. In Barker, P. F., Kennett, J. P., et al., Proc. ODP, Sci. Results, 113: College Station, TX (Ocean Drilling Program), 865-880.

Kent, D., Opdyke, N. D., and Ewing, M., 1971. Climatic change in the North Pacific using ice-rafted detritus as a climatic indicator. Geol. Soc. Am. Bull., 82:2741-2754.

Krinsley, D., and Donahue, J., 1968. Environmental interpretation of sand grain surface features by electron microscopy. Geol. Soc. Am. Bull., 79:743-748.

Leg 119 Shipboard Scientific Party, 1988. Early glaciation of Antarctica. Nature, 333:303-304.

Leg 120 Scientific Drilling Party, 1988. Leg 120 explores origins and history. Geotimes, 33:12-16.

LeMasurier, W. E., and Rex, D. C., 1982. Volcanic record of Cenozoic glacial history in Marie Byrd Land and western Ellsworth Land: revised chronology and evaluation of tectonic factors. In Craddock, C. (Ed.), Antarctic Geoscience: Madison (Univ. Wisconsin Press), 725-734.

1983. Rates of uplift and the scale of ice level instabilities recorded by volcanic rocks in Marie Byrd Land, West Antarctica. In Oliver, R. L., James, P. R., and Jago, J. B. (Eds.), Antarctic Earth Science: Cambridge (Cambridge Univ. Press), 663-670.

Margolis, S. V., and Kennett, J. P., 1971. Cenozoic paleoglacial history of Antarctica recorded in subantarctic deep-sea cores. Am. J. Sci., 271:1-36.

Margolis, S. V., and Krinsley, D. H., 1974. Processes of formation and environmental occurrence of microfeatures on detrital quartz grains. Am. J. Sci., 274:449-464.

Matthews, R. K., and Poore, R. Z., 1980. Tertiary $\delta^{18} \mathrm{O}$ record and glacio-eustatic sea-level fluctuations. Geology, 8:501-504.

Mercer, J. H., 1973. Cainozoic temperature trends in the Southern Hemisphere: Antarctic and Andean glacial evidence. In van Bakker, E. M. (Ed.), Paleoecology of Africa and of the Surrounding Islands and Antarctica (Vol. 8): Cape Town (Balkema), 85-114. 1978. Glacial development and temperature trends in the Antarctic and in South America. In Bakker, E. M. (Ed.), Antarctic 
Glacial History and World Palaeoenvironments: Rotterdam (Balkema), 73-93.

Mildenhall, D. C., 1989. Terrestrial palynology. In Barrett, P. J. (Ed.), Antarctic Cenozoic History from the CIROS-I Drillhole, McMurdo Sound: DSIR Bull. N. Z., 245:119-127.

Miller, K. G., and Fairbanks, R. G., 1983. Evidence for Oligocenemiddle Miocene abyssal circulation changes in the western North Atlantic. Nature, 306:250-252.

Miller, K. G., Fairbanks, R. G., and Mountain, G. S., 1987. Tertiary oxygen isotope synthesis, sea-level history, and continental margin erosion. Paleoceanography, 2:1-19.

Miller, K. G., Mountain, G. S., and Tucholke, B. E., 1985. Oligocene glacio-eustasy and erosion on the margins of the North Atlantic. Geology, 13:10-13.

Miller, K. G., and Thomas, E., 1985. Late Eocene to Oligocene benthic foraminiferal isotopic record, Site 574, equatorial Pacific. In Mayer, L., Theyer, F., et al., Init. Repts. DSDP, 85: Washington (U.S. Govt. Printing Office), 771-777.

Oberhänsli, H., McKenzie, J. A., Toumarkine, M., and Weissert, H. 1984. A paleoclimatic and paleoceanographic record of the Paleogene in the central South Atlantic (Leg 73, Sites 522, 523, and 524). In Hsü, K. J., LaBrecque, J. L., et al., Init. Repts. DSDP, 73: Washington (U.S. Govt. Printing Office), 737-747.

Oerlemans, J., 1982. A model of the Antarctic ice sheet. Nature, 297:550-553.

Officer, C. B., 1982. Mixing, sedimentation rates, and age dating for sediment cores. Mar. Geol., 46:261-278.

Peng, T.-H., Broecker, W. S., and Berger, W. H., 1979. Rates of benthic mixing in deep-sea sediments as determined by radioactive tracers. Quat. Res., 11:141-149.

Poore, R. Z., and Matthews, R. K., 1984. Oxygen isotope ranking of late Eocene and Oligocene planktic foraminifers: implications for Oligocene sea-surface temperatures and global ice-volume. Mar. Micropaleontol., 9:111-134.

Prentice, M. L., and Matthews, R. K., 1988. Cenozoic ice-volume history: development of a composite oxygen isotope record. Geology, 16:963-966.

Savin, S. M., 1977. The history of the earth's surface temperature during the past 100 million years. Annu. Rev. Earth Planet. Sci. 5:319-355.

Savin, S. M., Douglas, R. G., and Stehli, F. G., 1975. Tertiary marine paleotemperatures. Geol. Soc. Am. Bull., 86:1499-1510.

Schlich, R., Wise, S. W., Jr., et al., 1989. Proc. ODP, Init. Repts., 120: College Station, TX (Ocean Drilling Program).

Shackleton, N. J., Hall, M. A., and Boersma, A., 1984. Oxygen and carbon isotope data from Leg 74 foraminifers. In Moore, T. C., Jr.,
Rabinowitz, P. D., et al., Init. Repts. DSDP, 74: Washington (U.S. Govt. Printing Office), 599-644.

Shackleton, N. J., and Kennett, J. P., 1975. Paleotemperature history of the Cenozoic and the initiation of Antarctic glaciation: oxygen and carbon isotope analyses in DSDP Sites 227,279 , and 281. In Kennett, J. P., Houtz, R. E., et al., Init. Repts. DSDP, 29: Washington (U.S. Govt. Printing Office), 743-756.

Vail, P. R., Mitchum, R. M., Jr., Todd, R. G., Widmier, J. M., Thompson, S., III, Sangree, J. B., Bubb, J. N., and Hatelid, W. G., 1977. Seismic stratigraphy and global changes of sea level. In Payton, C. E. (Ed.), Seismic Stratigraphy-Applications to Hydrocarbon Exploration. AAPG Mem., 26:49-221.

Warnke, D. A., 1970. Glacial erosion, ice-rafting, and glacial marine sediments: Antarctica and the Southern Ocean. Am. J. Sci., 269:276-294.

Webb, P. N., Harwood, D. M., McKelvey, B. C., Mercer, J. H., and Stott, L. D., 1984. Cenozoic marine sedimentation and ice-volume variation on the East Antarctic craton. Geology, 12:287-291.

Wei, W., and Wise, S. W., Jr., in press. Latitudinal biogeographic gradient of late Paleogene calcareous nannoplankton in the South Atlantic Ocean. In Proto-Decima, F., Reale, V., and Monechi, S. (Eds.), Proc. Int. Nannoplankton Assoc. Meeting, Florence, 1989. Mem. Sci. Geol., Univ. Padova.

Wise, S. W., Jr., Breza, J. R., Harwood, D. M., and Wei, W., 1991. Paleogene glacial history of Antarctica. In McKenzie, J. A., Müller, D. W., and Weissert, H. (Eds.), Controversies in Modern Geology: England (Cambridge).

Wise, S. W., Jr., Gombos, A. M., and Muza, J. P., 1985. Cenozoic evolution of polar water masses, southwest Atlantic Ocean. In Hsü, K. J., and Weissert, H. J. (Eds.), South Atlantic Paleoceanography: Cambridge (Cambridge Univ. Press), 283-324.

Wise, S. W., Jr., Hay, W. W., O'Connell, S., Barker, P. F., Kennett, J. P., Burckle, L. H., Egeberg, P. K., Fütterer, D. K., Gersonde, R. E., Golovchencko, X., Hamilton, N., Lazarus, D. B., Mohr, B., Nagao, T., Pereira, C.P.G., Pudsey, C. J., Robert, C. M., Schlandl, E., Spieß, V., Stott, L. D., Thomas, E., and Thompson, K.F.M., 1987. Early Oligocene ice on the Antarctic continent. Geol. Soc. Am. Abstr. Programs, 19:893. (Abstract)

Zinsmeister, W. J., 1978. Effect of formation of the West Antarctic Ice Sheet on shallow water marine faunas of Chile. Antarctic J. U.S., 13:25-26.

Date of initial receipt: 1 March 1990

Date of acceptance: 13 March 1991

Ms 120B-134 